Egyptian Journal of Aquatic Biology \& Fisheries

Zoology Department, Faculty of Science,

Ain Shams University, Cairo, Egypt.

ISSN $1110-6131$

Vol. 23(2): 613 - 637 (2019)

www.ejabf.journals.ekb.eg

\title{
A comparison of the severity of white spot disease in cultured shrimp (Fenneropenaeus indicus) at a farm level in Egypt I-Molecular, histopathological and field observations
}

\author{
Mohamed E. Megahed \\ National Institute of Oceanography and Fisheries (NIOF), Gulfs of Suez \& Aqaba's \\ Branch, Attaka, Suez, P.O. Box.: 182, Postal code: 43511, Egypt. \\ E-mail: aquageimprove@gmail.com
}

\section{ARTICLE INFO \\ Article History: \\ Received: March 22, 2019 \\ Accepted: Aug. 25, 2019 \\ Online: Sept. 2019}

\section{Keywords: \\ Fenneropenaeus indicus PCR \\ Histopathology \\ Cultured shrimp \\ Growth performance}

Since 2009, white spot syndrome virus (WSSV) has been detected in cultured shrimp Fenneropenaeus indicus and caused severe mortalities in cultured penaeid shrimp in Egypt. The results showed that the variation of WSSV loads was correlated with DO, temperature and ammonia-N concentrations $\left(\mathrm{NH}_{4}\right)$. These results suggested that maintaining high level DO, high water temperature and low level of ammonia might prevent the diseases outbreak and mortality. This study investigated the occurrence of WSD in cultured $F$. indicus in shrimp farms of Egypt using $\mathrm{H} \& \mathrm{E}$ histopathology and PCR examinations. F. indicus shrimps obtained from ponds experiencing no WSD outbreaks (ISHNO) and ponds experiencing outbreaks (MMWO) showed typical clinical signs of WSD. The results of morphometrics showed no difference between ISHNO and MMWO and the WSSV does not affect the growth or body shape of the shrimp. Overall, the histopathological changes in the tissues of the shrimp from ISHNO and MMWO ponds were similar but the severity of changes was more in MMWO compared to ISHNO. A total of 16 Haemolymph and 22 gill tissues were collected from ISHNO and MMWO were tested by PCR. The samples were all tested positive for WSSV by IQ2000 WSSV DPS. The MMWO shrimp samples appear to have stronger band intensity compared to the ISHNO, this explains why MMWO experienced mortalities earlier time than ISHNO. There were differences in the number and percentage of infected shrimp between female and male in both ISHNO and MMWO. In ISHNO farms, 2047 (68.23\%) female and 953 male (31.76\%) infected by WSSV. In MMWO farms, 2078 (69.26\%) female and 922 (30.73\%) male infected by WSSV. The effect of WSSV was not significant on the growth rate and survival during production cyscle. However, mortality occurs at a certain point of time and affects the whole ponds. This was clear where massive mortalities occurred earlier in MMWO than ISHNO after 16 weeks (day 112) of culture.

\section{INTRODUCTION}

Over the past decades shrimp pathogens have been expanded (Lightner, 1999; Rodriguez et al., 2003), and caused economic losses for the shrimp farming (Wyban et al., 1992; Lightner, 1999; Lo et al., 1999). WSSV is the major pathogenic virus in Penaeidae family (Lightner, 1996), and was reported first in Marsupenaeus japonicus in Taiwan (Chen, 1995), in Penaeus monodon in Asian countries (Lo et 
al., 1999), in Fenneropenaeus indicus in Iran (Afsharnasab et al., 2009) and Saudi Arabia (Tang et al., 2012). Over the past 10 years shrimp farming in Egypt has been severely affected by disease outbreaks leading to major economic losses to shrimp farmers. Disease outbreaks in shrimp in Egypt dates back to 2009 in F. indicus and in 2015 in F. indicus and Litopenaeus vannamei. Periodic disease outbreak such as white spot disease (WSD) has been a bottleneck for the growth and expansion of shrimp aquaculture in Egypt (Megahed et al., 2013a). In Egypt, some farmers at Dibah Triangle Zone (DTZ) are able to obtain a reasonably good harvest despite the presence of WSSV infection, while others suffer major losses due to high mortalities (Pers. Comm. shrimp farmers in the DTZ). These observations suggest the existence of possible variation in virulence of WSSV (i.e. 'virulent' and 'less-virulent' strain) as reported by other researchers in the past (Fegan et al., 1991; Flegel 1997a,b; Owens et al., 1998; Lan et al., 2002). Based on the observed differences in WSSV virulence, two cases of shrimp farms were identified in DTZ; 1) Shrimp farms were suffering from mass mortalities due to WSD outbreaks which were referred as "mass mortality with outbreak" and abbreviated as (MMWO), and 2) despite the presence of WSD, farmers successfully harvested their ponds without any mass mortality. This was referred in this work as "infected but succeeded to harvest with no outbreaks, ISHNO".

The clinical signs in $F$. indicus samples from both ISHNO and MMWO farms were recorded. The samples were examined for WSSV clinical signs, histopathology and polymerase chain reaction (PCR). Water quality parameters, growth performance and morphometrics of samples originated from both cases were measured at a regular time intervals. Histopathology and PCR results confirmed the presence of WSSV in both ISHNO and MMWO farms. Based on the PCR results, it appears that samples originated from MMWO farms had a higher levels of WSSV infection compared to those that were collected from ISHNO farms. Adults $F$. indicus showed complete dimorphism where female are larger than male, and the prevalence of WSSV in female was higher than male $(68.23 \%$ vs. $31.76 \%$ and $69.26 \%$ vs. $30.73 \%$ in ISHNO and MMWO, respectively). To obtain information about the farm management in both cases, farmers were questioned about the management of shrimp farms starting from pond preparation till harvest. They explained that pond preparations were carried out by sun drying, liming, addition of organic fertilizers and water filling. Essential part of pond preparation was to ensure that water quality is suitable for post larvae (PL) stocking. Hapa test was used to verify the readiness of the pond for PL stocking, the test included; stocking 100 PL and estimation the survival after 48 hours. If survival was less than $90 \%$, stocking was postponed and water quality was checked for correction actions to make sure that ponds are suitable for stocking. Growth performance parameters of ISHNO and MMWO were not affected by the WSSV outbreaks. There were significant differences between ISHNO and MMWO in ammonia, dissolved oxygen (DO), and water temperature which might have contributed to large-scale mortalities in MMWO ponds than ISHNO. Considering the fact that WSD is present in Egypt, and there is no anti-viral therapy, adopting proper farm management practices could mitigate the risk of WSD outbreak and enable a successful harvest despite the presence of the WSD. There are several reports in the literature indicating a relationship between viral infection and physiochemical stress, such as salinity, temperature, DO, among others (Tsai et al., 1999; Kautsky et al., 2000 ; Vidal et al., 2001; Guan et al., 2003; Yu et al., 2003; Lotz et al., 2005 ; Liu et al., 2006; Peinado and López, 2006; Rahman et al., 2006 ; Sánchez-Martínez et al., 2007; Ruiz-Velazco et al., 2010; Tendencia et al., 2010; Tendencia and Verreth, 
2008). The ability of shrimp to carry WSSV for relatively long periods under good farming conditions has been previously reported (Clifford, 1985; Tsai et al., 1999; Withyachumnarnkul, 1999; Khadijah et al., 2003; Lawrence et al., 2001).

To accurately confirming the observation that some shrimp farms can survive till harvest under infection by WSSV and other farms cannot survive under same infection by WSSV. This study investigated one production cycle starting from pond preparation till harvest. To my knowledge, this is the first report dealing with such observation on WSD severity in cultured $F$. indicus in Egypt. Therefore, the objective of this study was to investigate the factors that contribute to the difference in WSD severity with an impact on survivability at harvest in shrimp farms in Egypt.

\section{MATERIALS AND METHODS}

\section{Study site}

The present study was carried out in two types of shrimp farms located at Dibah Triangle Zone (DTZ), Port-Said, in 2015 (Fig. 1). DTZ is an important aquaculture site for shrimp farming including, F.indicus, L. vannamei, M. japonicus and $P$. semisulcatus. This study was initiated based on the observation that there were two categories of shrimp farms in DTZ were affected by WSD. In the first category, shrimp was "infected but succeeded to harvest with no outbreaks", abbreviated as "ISHNO". The ISHNO farms were located in the first row that takes water directly from the Mediterranean Sea (Fig.1). The second category of farms experienced "mass mortality with outbreak" abbreviated as "MMWO". The MMWO farms were located in the second and third row that takes low quality water, mixed with the discharge water of the first row of farms (ISHNO) in addition to water intake from Lake Manzala (Fig.1). In order to identify factors that may contribute to the difference in disease severity between ISHNO and MMWO, data were recorded for pond preparation, water quality and sampling for growth performances.

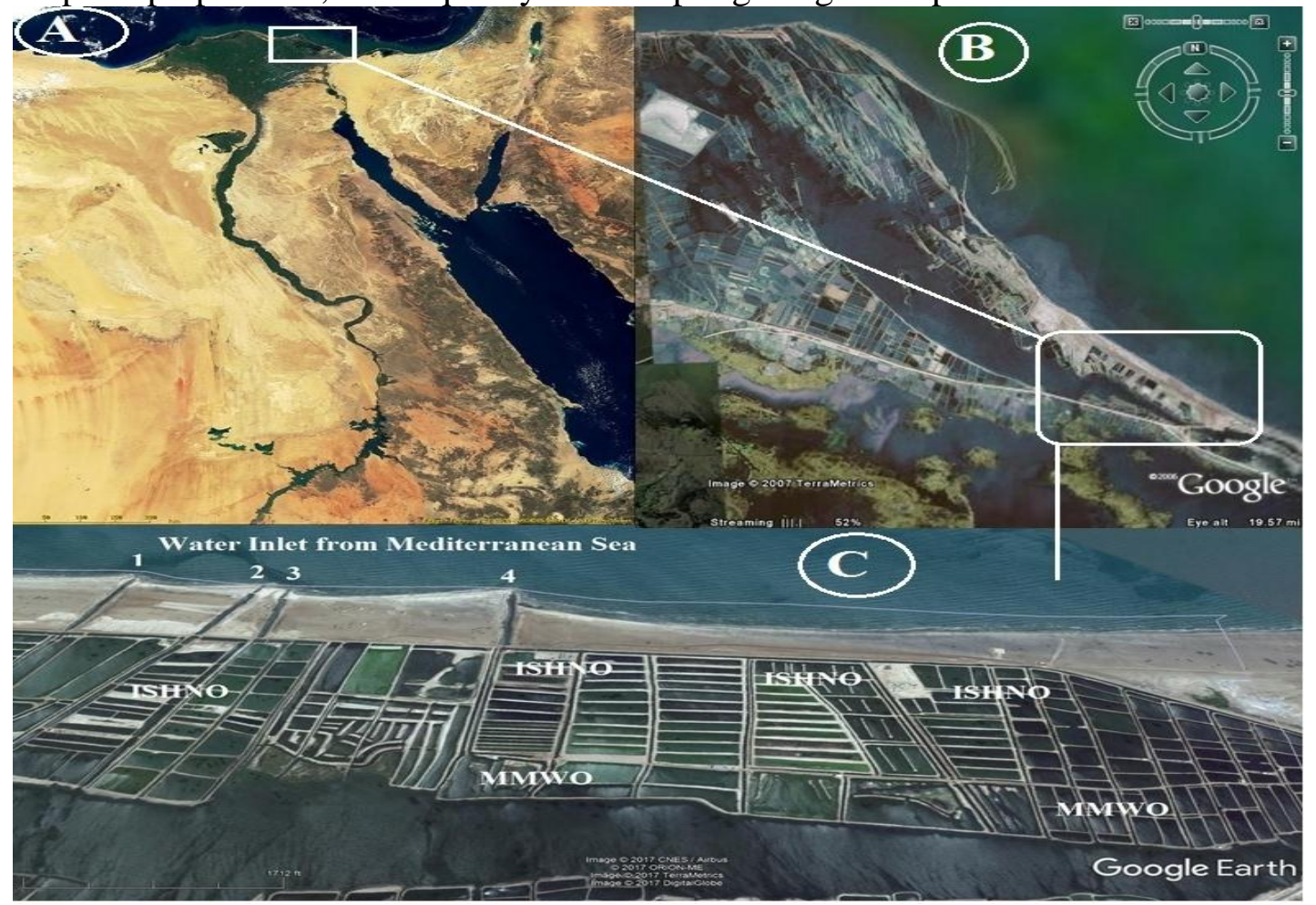

Fig. 1: Satellite map shows (A) Egypt map including (B) the Dibah Triangle Zone (DTZ) and (C) layout of ISHNO and MMWO shrimp growout ponds. 


\section{Pond preparation}

Pond preparation included, pond flushing, sun drying, dike and slope maintenance, liming, fertilization, water culture and installation of aeration systems. The flushing of pond bottom was carried out during 6 to 12 hours in order to eliminate the accumulated sludge sediment in the pond bottom, followed by sun drying for 10 to 15 days. Dike and slope work carried out during daytime and repaired if erosion occurred during the last crop. The lime dosage adjusted according to the results of $\mathrm{pH}$ analysis. Liming for soil $\mathrm{pH}$ correction up to 7.0 by agricultural lime $\left(\mathrm{CaCO}_{3}\right)$. Agricultural /hydrated lime was spread out over the pond bottom as evenly as possible just prior to refilling the pond. Liming for disinfection was carried out using $1000 \mathrm{~kg} / \mathrm{ha}$ hydrated lime. Fertilization and water culture included, $30 \mathrm{~kg}$ of dried chicken manure was applied by broadcasting throughout the pond, Water filling up to $5-10 \mathrm{~cm}$ and left for 1 day, followed by water filling to $70 \mathrm{~cm}$ (left for 2 days) and $100 \mathrm{~cm}$ (left for 2 days) and finally pond water leveled at $120 \mathrm{~cm}$. For maintaining water bloom, chicken manure was tied at post near inlet gate. Inorganic fertilizers were applied (20 kg Urea $+5 \mathrm{~kg}$ diammonium phosphate, DAP) by broadcasting throughout the pond. The inorganic fertilizers were soaked in fresh water for 24 hours. $7 \mathrm{~kg}$ of Urea and $3.5 \mathrm{~kg}$ of DAP (maintenance application) was required to maintain the bloom. Water transparency was checked daily, if it reaches $40-60 \mathrm{~cm}$ with a secchi disk, shrimps were stocked after acclimation. Paddlewheels were operated to maintain DO in the pond at optimum levels (DO>5.0 mg/L). Paddlewheels were cleaned by rinsing with fresh water; barnacles scraped away, filamentous algae and excess feed scum sticking to paddlewheels floats and paddles. Paddlewheels were treated with 40 ppm chlorine; making sure chlorine was washed off completely and dries thoroughly. Paddlewheels turned off during strong wind.

\section{Water quality parameters}

Water quality parameters, such as ammonia (mg/L), DO (mg/L), pH, Temp $\left({ }^{\circ} \mathrm{C}\right)$, Transparency $(\mathrm{cm})$ and salinity (ppt) were monitored in both categories of shrimp farms (ISHNO and MMWO) using YSI Plus model 550 (YSI, USA) at 06:00 $\mathrm{AM}$ and 04:30 $\mathrm{PM}$ on a daily basis. Ammonia $\mathrm{NH}_{4}(\mathrm{mg} / \mathrm{L})$ was analyzed spectrophotometrically according to standard methods (APHA, 1998).

\section{Growth performance parameters and morphometrics}

Growth performance parameters were estimated by regular sampling. Survival rate of the shrimp in each pond category was calculated using the formula:

$\mathrm{S}=100 \mathrm{x}(\mathrm{nt} / \mathrm{n} 0)$,

Where: $\mathrm{S}$ is the survival rate; $\mathrm{nt}$ is the number of the shrimp at time $\mathrm{t}$ and $\mathrm{n} 0$ is the number of shrimp at the beginning of the study.

Growth rate was calculated and expressed as average weekly gain (AWG) and feed conversion ratio (FCR) according to the following equations:

$\mathrm{AWG}(\mathrm{g} / \mathrm{week})=(\mathrm{Wf}-\mathrm{Wo}) / \mathrm{wk}$

Where: Wf is weight of the animal at time t; Wo is weight at the beginning of the study; wk are the week number in the growth period.

Feed conversion ratio $(\mathrm{FCR})=$ feed intake $($ dry matter $)(\mathrm{g}) /$ weight gain $(\mathrm{g})$.

All parameters were compared the target growth performances values in which shrimp farmers wishing to obtain the best scenarios from previous harvest in the past).

Six morphometric measurements were collected on random sample WSSVinfected male and female shrimp from ISHNO and MMWO farms. The morphometric measurements included weight at collection (CollWt) to the nearest $0.01 \mathrm{~g}$, tail volume (TailV), head length (HeadL), tail length (TailL), maximum head 
thickness (MaxHThick), tail thickness (TailTK), and maximum thickness of six somite (Max6Somite) (Fig. 2).

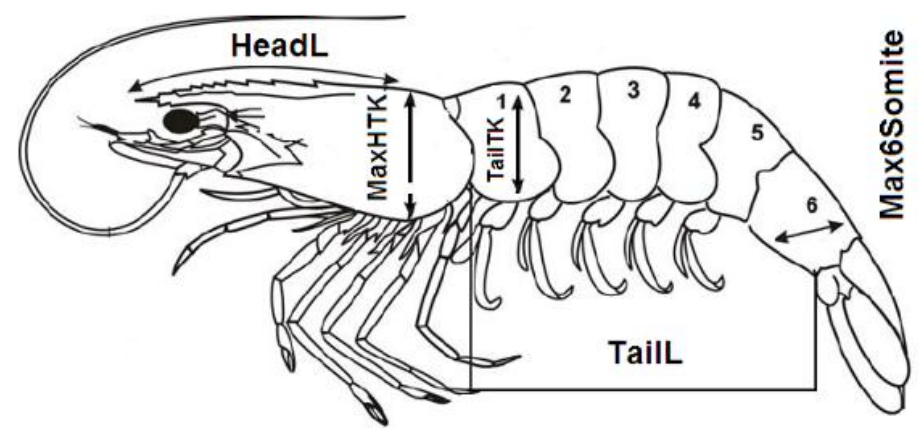

Fig. 2: The morphometric measurements taken on female and male shrimp from ISHNO and MMWO shrimp ponds.

\section{Clinical signs and Histopathology}

A total 2000 shrimp representative 5 sub-samples of 200 shrimp each from ISHNO and MMWO ponds were used to calculate the WSSV prevalence between females and males shrimp. For the identification of clinical signs and conformation of WSSV infection. Sampling was performed from May to November 2015. A 150 shrimp samples (juvenile, sub adult and adult) accompanying with WSSV infection were randomly collected from shrimp ponds (ISHNO and MMWO) of $F$. indicus (average weight 16-21 g) with opaque, whitish abdominal muscles and white, milky spot on carapace body cuticle (Fig.3). In both categories of shrimp farms, generally the pond sizes varied from 0.5 to 1.0 ha although occasionally there were few farms that were more than 1.0 ha.

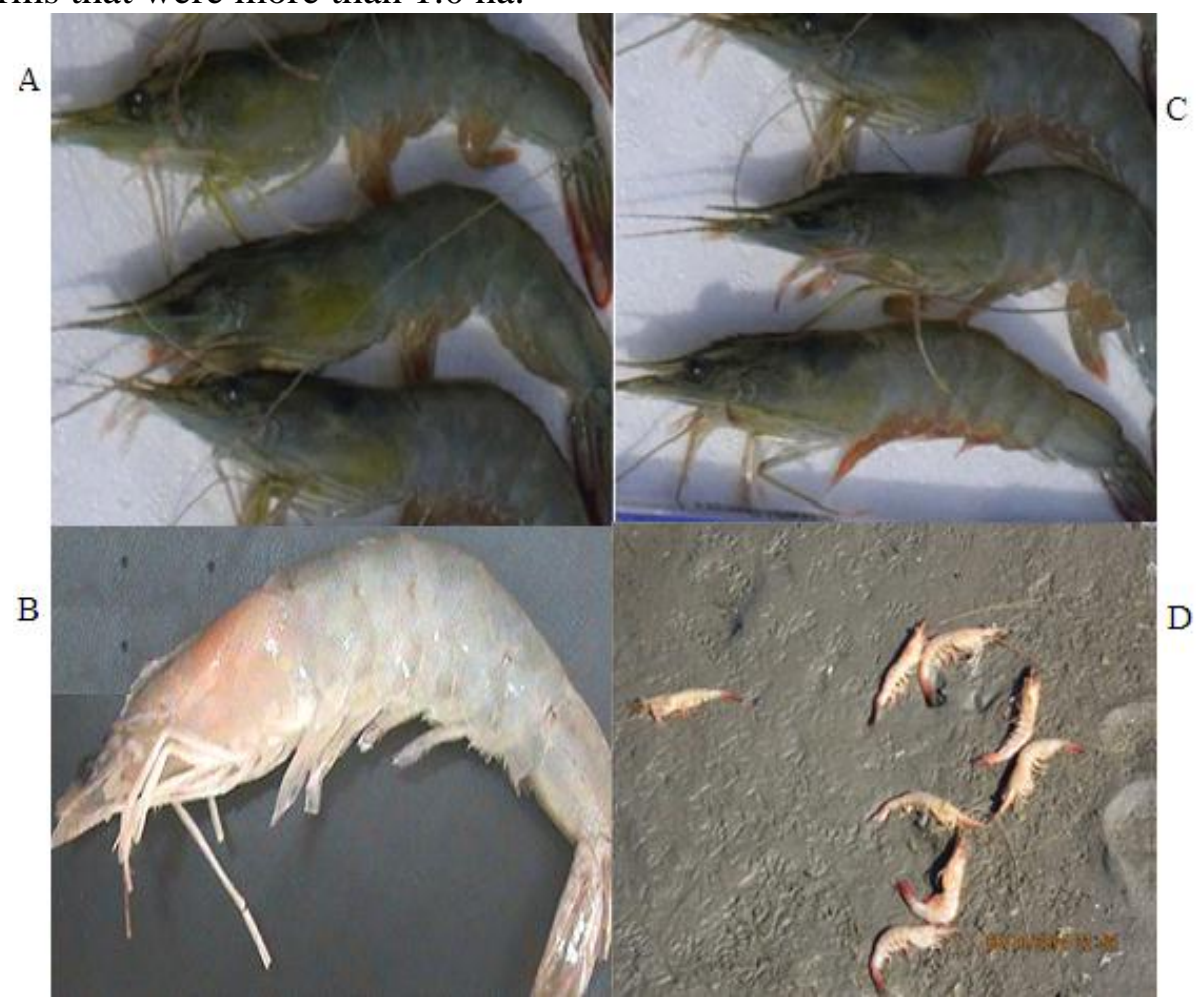

Fig. 3: Clinical signs of WSSV infected shrimp collected from ponds of ISHNO (A: live shrimp and B: moribund shrimp) and MMWO (C: live shrimp and D: moribund shrimp). 
The stocking density was equivalent in both categories of farms at $25 \mathrm{PL} / \mathrm{m}^{2}$. Shrimp samples were kept on ice and examined for gross signs of WSSV. The Juveniles, sub adults and adult shrimps were injected with cold Davidson's fixative solution $\left(4^{\circ} \mathrm{C}\right)$ into the hepatopancreas, gills and 2, 4 and 6 abdominal segmental tissues, and fixed for $48 \mathrm{~h}$ (ratio 1:10), then the samples preserved in $50 \%$ ethyl alcohol for histopathological analysis (Bell and Lightner, 1988). Samples were processed for histology following the methods outlined in Bell and Lightner (1988). Subsequently gross signs of WSSV were evaluated using light microscope (CETI; Triton II).

\section{Polymerase chain reaction (PCR)}

The confirmation of WSSV infection was carried out using IQ2000 ${ }^{\mathrm{TM}}$ WSSV detection and prevention system (IQ2000 WSSV DPS, GeneReach, Taiwan) following manufacturer's protocol. DNA extracted using QIAamp DNA Mini kit (Qiagen, CA, USA) and yielded 0.18 to $0.90 \mathrm{~g}$ of DNA per mg of tissue. The thermal profile for the first round of PCR included an initial denaturation at $94^{\circ} \mathrm{C}$ for two min, followed by 15 cycles of $94^{\circ} \mathrm{C}$ for $20 \mathrm{sec}, 62^{\circ} \mathrm{C}$ for $20 \mathrm{sec}$ and $72^{\circ} \mathrm{C}$ for $30 \mathrm{sec}$, and a final cycle of $72^{\circ} \mathrm{C}$ for $30 \mathrm{sec}$ and $20^{\circ} \mathrm{C}$ for $20 \mathrm{sec}$. The temperature for the nested PCR was, 30 cycles of $94^{\circ} \mathrm{C}$ for $20 \mathrm{sec}, 62^{\circ} \mathrm{C}$ for $20 \mathrm{sec}$ and $72^{\circ} \mathrm{C}$ for $30 \mathrm{sec}$ and one cycle of $72^{\circ} \mathrm{C}$ for $30 \mathrm{sec}$ and $20^{\circ} \mathrm{C}$ for $20 \mathrm{sec}$. PCR products were analyzed by $1.5 \%$ agarose gel electrophoresis, and the gel images were captured using a Safe Blue Imager System (Major Science, U.S.A).

\section{Statistical analysis}

Statistical analysis was performed using SPlus v 8.0 for Windows (Insightful Corp.). A Student's t- test was used to test the significant differences between ISHNO and MMWO regarding water quality parameters, growth performance and morphometric. Significant differences was considered when $P$-value $<0.05$.

\section{RESULTS}

\section{Water quality}

In this study water quality parameters were monitored continually during the production cycle in ISHNO and MMWO shrimp ponds to find out if there is a relationship between WSD outbreaks and water quality (Fig. 4a and 4b). The results showed that the variation of WSSV loads was correlated with ammonia-N concentrations $\left(\mathrm{NH}_{4}\right), \mathrm{DO}$ and temperature. These results suggested that maintaining low level of ammonia, high level DO and optimum water temperature might prevent the WSD diseases outbreak and associated mortality. In ISHNO ponds, there were significant differences $(P<0.05)$ between average DO morning and afternoon $(3.88 \pm 0.62$ and $7.13 \pm 0.79 \mathrm{mg} / \mathrm{L}), \mathrm{NH}_{4}(2.37 \pm 0.65$ and $2.63 \pm 0.70 \mathrm{mg} / \mathrm{L})$ and transparency $(56.80 \pm 9.83 \mathrm{~cm}$ and $52.31 \pm 14.19 \mathrm{~cm})$, respectively. No significant differences $(P>0.05)$ were found in temperature, $\mathrm{pH}$ and salinity in ISHNO shrimp ponds. However, in MMNO ponds, $\mathrm{NH}_{4}$ and $\mathrm{DO}$ levels were not in the acceptable level for shrimp farming. The DO levels were fluctuating and most of the time low oxygen levels recorded throughout the production cycle. The range of DO levels ranged from $1.26 \pm 0.58 \mathrm{mg} / \mathrm{L}$ to $2.94 \pm 0.58 \mathrm{mg} / \mathrm{L}$ and from $3.61 \pm 0.75 \mathrm{mg} / \mathrm{L}$ to $5.96 \pm 0.75 \mathrm{mg} / \mathrm{L}$, in the morning and afternoon, respectively. The range of $\mathrm{NH}_{4}$ levels was from $2.64 \pm 0.64 \mathrm{mg} / \mathrm{L}$ to $4.98 \pm 0.64 \mathrm{mg} / \mathrm{L}$ and from $3.26 \pm 0.38 \mathrm{mg} / \mathrm{L}$ to $4.42 \pm 0.38$ $\mathrm{mg} / \mathrm{L}$ during the entire production cycle, in the morning and afternoon, respectively. 
The range of temperature was $24.30 \pm 1.60{ }^{\circ} \mathrm{C}-28.79 \pm 1.60{ }^{\circ} \mathrm{C}$, and $29.08 \pm 1.60{ }^{\circ} \mathrm{C}-$ $34.57 \pm 1.60^{\circ} \mathrm{C}$, in the morning and afternoon, respectively.

A

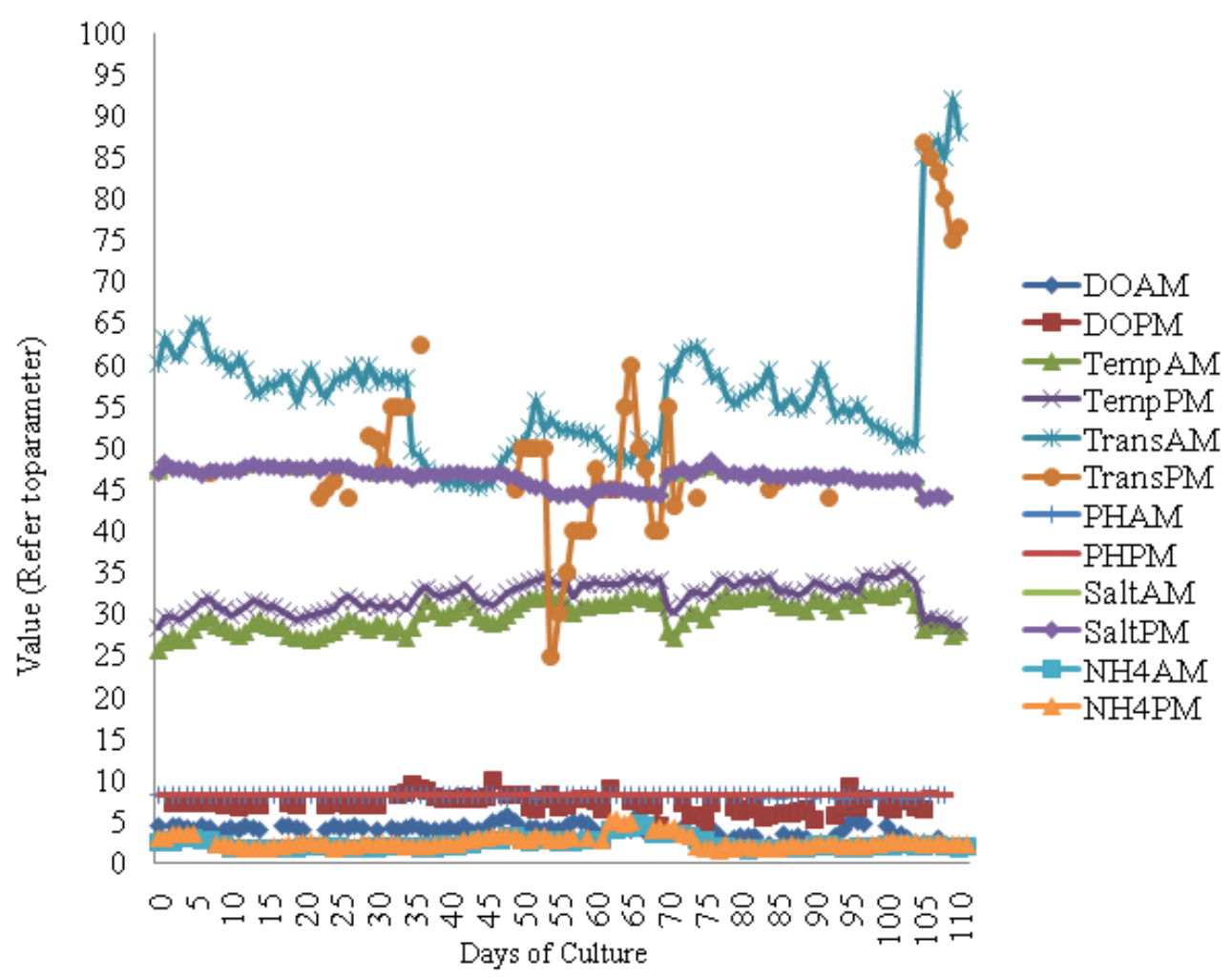

B

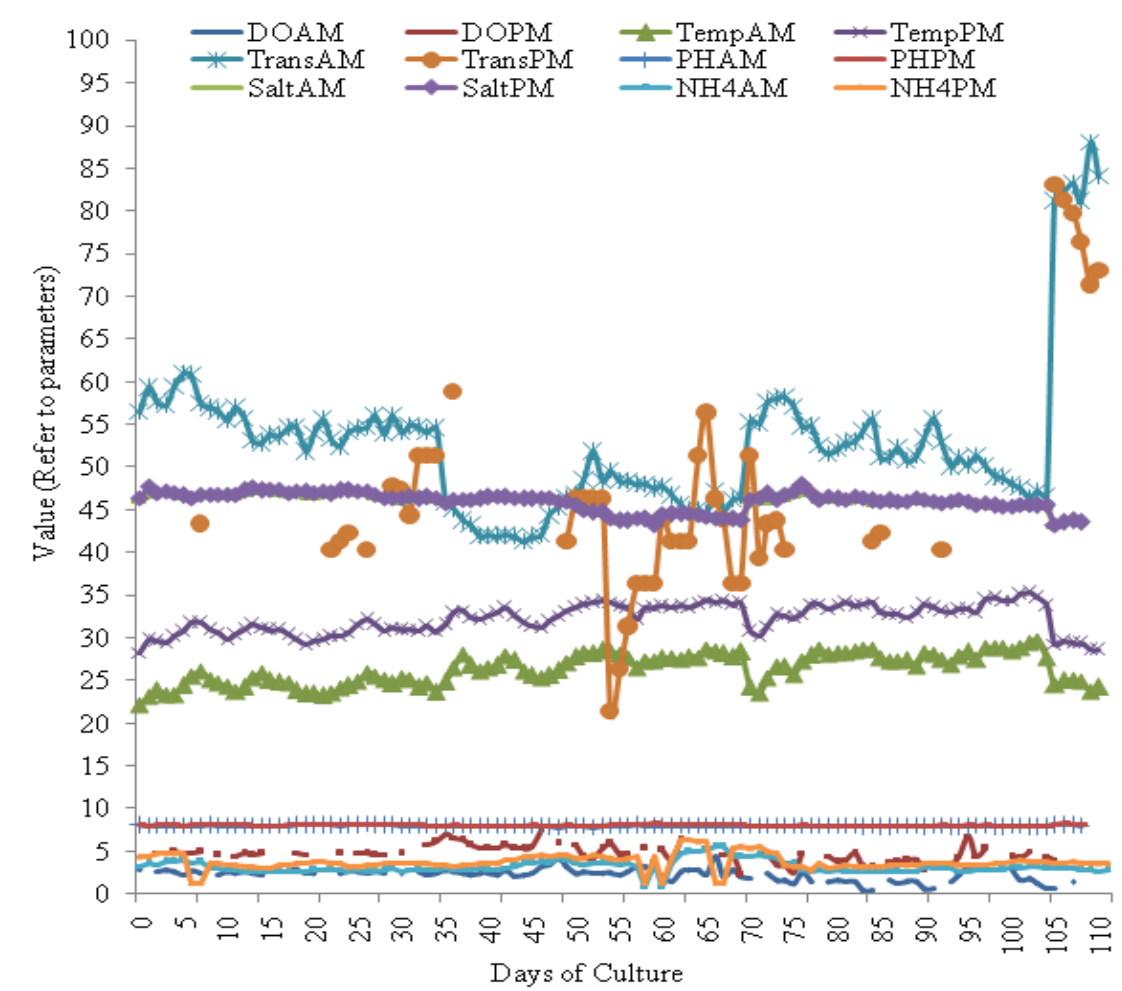

Fig. 4. Variations of water DO $(\mathrm{mg} / \mathrm{L})$, Temp $\left({ }^{\circ} \mathrm{C}\right)$, Transparency $(\mathrm{cm}), \mathrm{pH}$, salinity (ppt) and $\mathrm{NH}_{4}(\mathrm{mg} / \mathrm{L})$ at 06:00 $\mathrm{AM}$ and 04:30 $\mathrm{PM}$ on a daily basis in (A) ISHNO and (B) MMWO shrimp ponds. 
No significant differences were found in $\mathrm{pH}$, transparency and salinity $(P>0.05)$. There were significant differences $(P<0.05)$ in average temperature in the morning between ISHNO and MMWO $\left(30.18 \pm 1.50^{\circ} \mathrm{C}\right.$ and $26.63 \pm 1.60^{\circ} \mathrm{C}$, respectively). However, there were no significant differences $(P>0.05)$ in the afternoon temperature between ISHNO and MMWO $\left(32.41 \pm 1.60^{\circ} \mathrm{C}\right.$ and $32.34 \pm 1.51^{\circ} \mathrm{C}$, respectively). The morning differences in water temperature might be a possible reason for shrimp mortalities observed in MMWO in the early morning.

\section{Growth performance parameters}

For growth parameters and yield, no significant differences $(P>0.05)$ were found between the shrimp ponds of ISHNO and MMWO (Figs.5-8). The farmers were able to recognize two categories; 1) actual and 2) the target (preferred) values of the shrimp growth performances. The effect of WSSV was not significant $(P$ $>0.05$ ) on the growth rate, survival, and total production. The only difference exist that mortality occurs earlier in MMWO than ISHNO after 16 weeks (day 112) of culture. In ISHNO the average final weight of the shrimp was $23.51 \pm 0.73 \mathrm{~g}$ and average survival rate $(\mathrm{S} \%)$ was $(62.1 \%)$, which was almost similar as the target survival (TgTS ) preferred by farmers (62.6\%). An average weekly growth gain (AWG) varied from week 3 (day 22) to week 24 (day 169) from $0.39 \pm 0.02 \mathrm{~g}$ to $0.97 \pm 0.00 \mathrm{~g}$, respectively, and the target AWG value for the same period was from 0.43 to 1.03 , respectively (Figs.6a and 6b). The feed conversion ratio (FCR) revealed no significant differences $(P>0.05)$ between all ISHNO shrimp ponds. However, FCR increases with the age of the shrimp from weak 3 (day 22) to week 24 (day 169), from $1.40 \pm 0.15$ to $1.83 \pm 0.09$, respectively, and the target FCR value for the same period was 0.78 to 2.45 , respectively (Figs.7a and $7 \mathrm{~b}$ ). The final biomass of $2984.43 \pm 27.22 \mathrm{~kg} \mathrm{ha}^{-1}$ in ISHNO growout ponds was significantly $(P<0.05)$ lower than the final biomass in MMWO growout ponds $3132.20 \pm 37.00 \mathrm{~kg} \mathrm{ha}^{-1}$ (Figs.5a and $5 \mathrm{~b})$. In the case of MMWO growout ponds, the average final weight of the shrimp was $20.00 \pm 1.00 \mathrm{~g}$ and average survival rate $(\mathrm{S} \%)$ was $60 \%$ which was less than the TgTS (68.94\%) and ISHNO growout ponds survival (65\%) for the same period of time (week 16, day 112 of culture) (Figs. 8a and 8b). There were significant differences $(P<0.05)$ in AWG between ISHNO and MMWO from week 3 $(1.60 \pm 0.31 \mathrm{~g}$ and $0.39 \pm 0.02 \mathrm{~g}$, respectively) to week $16(0.98 \pm 0.04 \mathrm{~g}$ and $1.25 \pm 0.00 \mathrm{~g}$, respectively). 
A

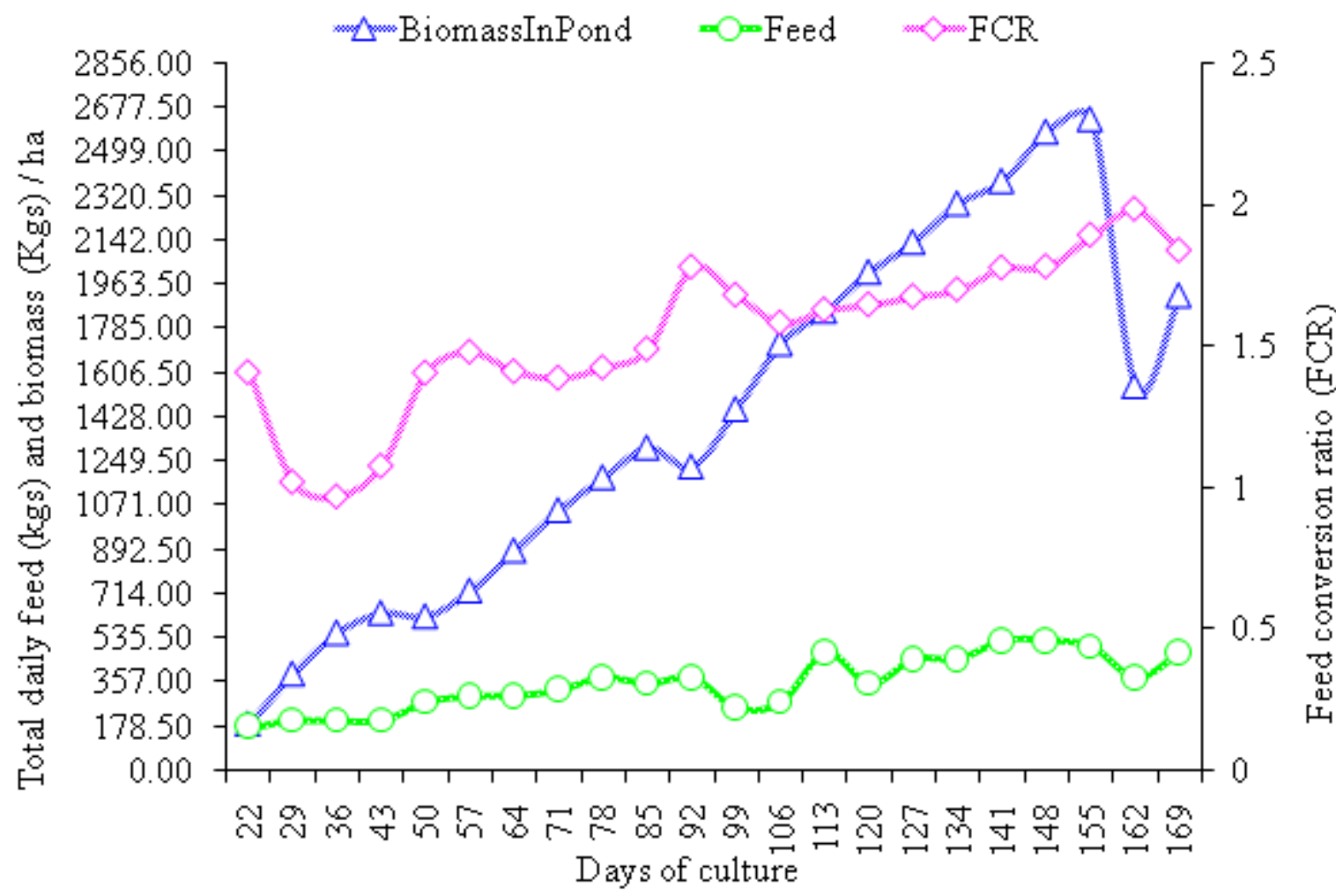

B

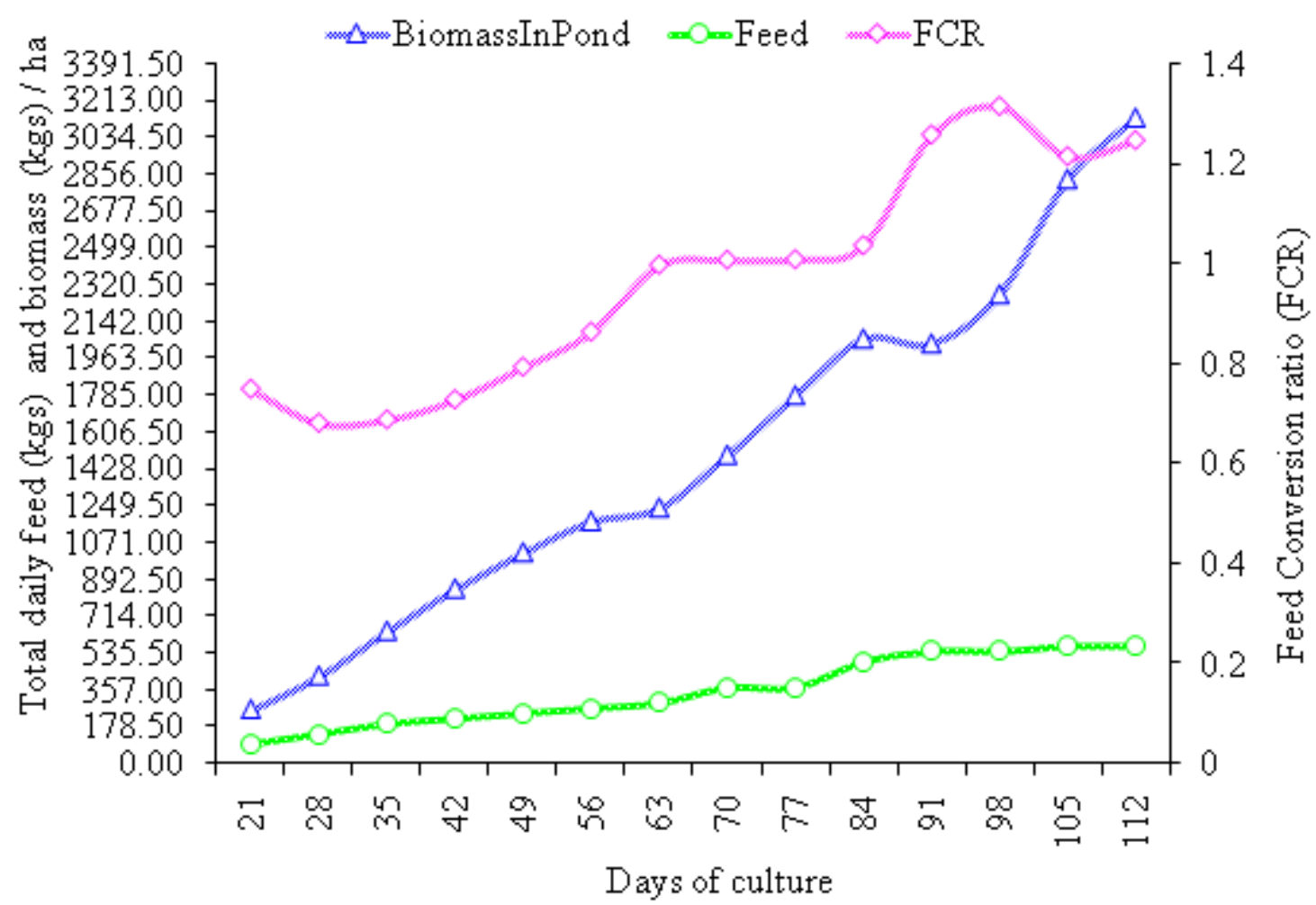

Fig. 5: Comparison chart of daily feed $(\mathrm{Kg})$, biomass $\left(\mathrm{Kg} \mathrm{ha}^{-1}\right)$ and FCR in (A) ISHNO and (B) MMWO shrimp ponds. 
Through the whole production cycle, the MMWO recorded higher AWG than ISHNO (Figs. 6a and 6a). The FCR of MMWO shrimp ponds revealed significant differences $(P<0.05)$ between all growout ponds.
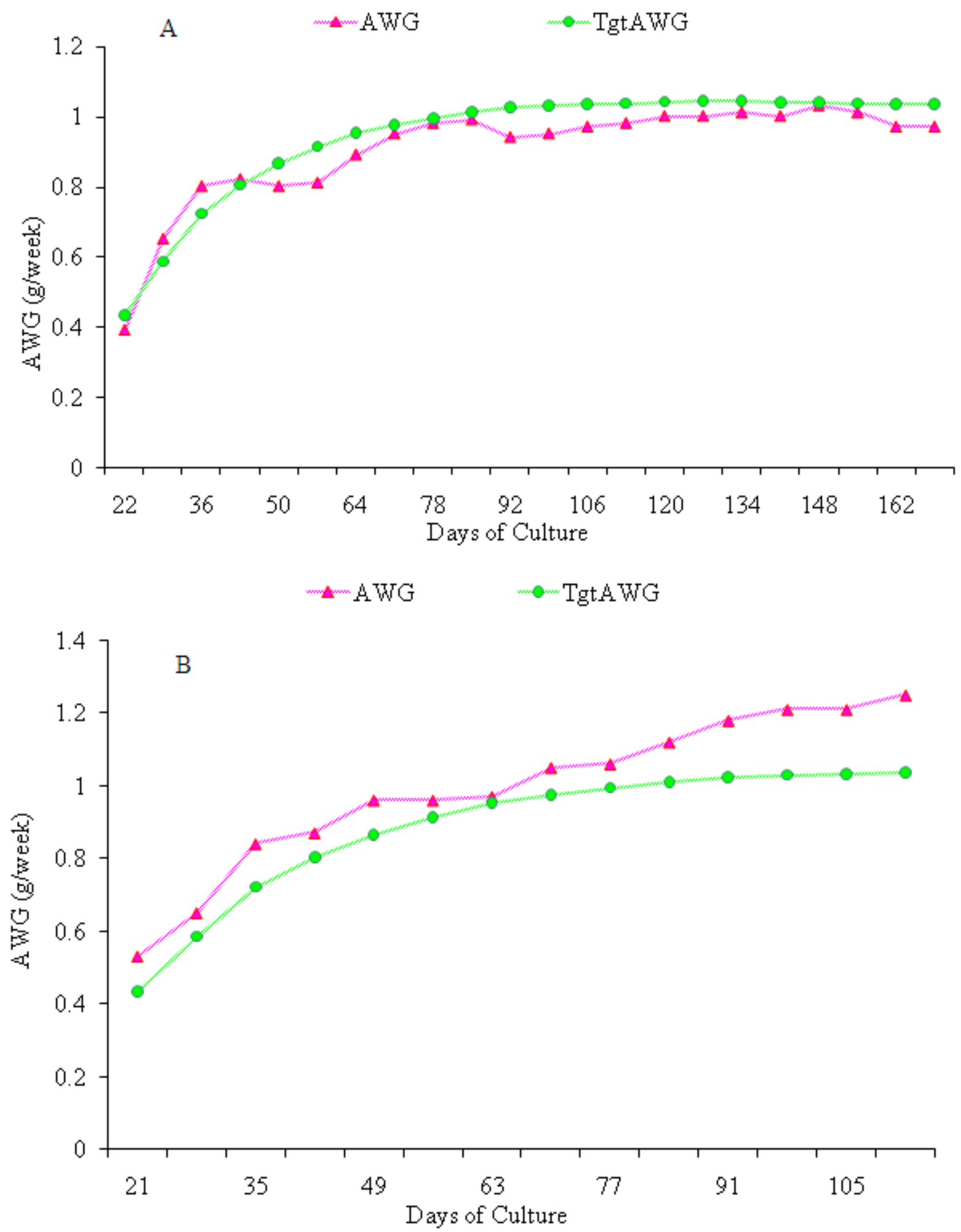

Fig. 6: Average weight gain $\left(\mathrm{g} \mathrm{week}^{-1}\right)$ of $F$. indicus shrimp in (A) ISHNO and (B) MMWO shrimp ponds. 
A $=\mathrm{ACR}=\mathrm{TgtFCR}$

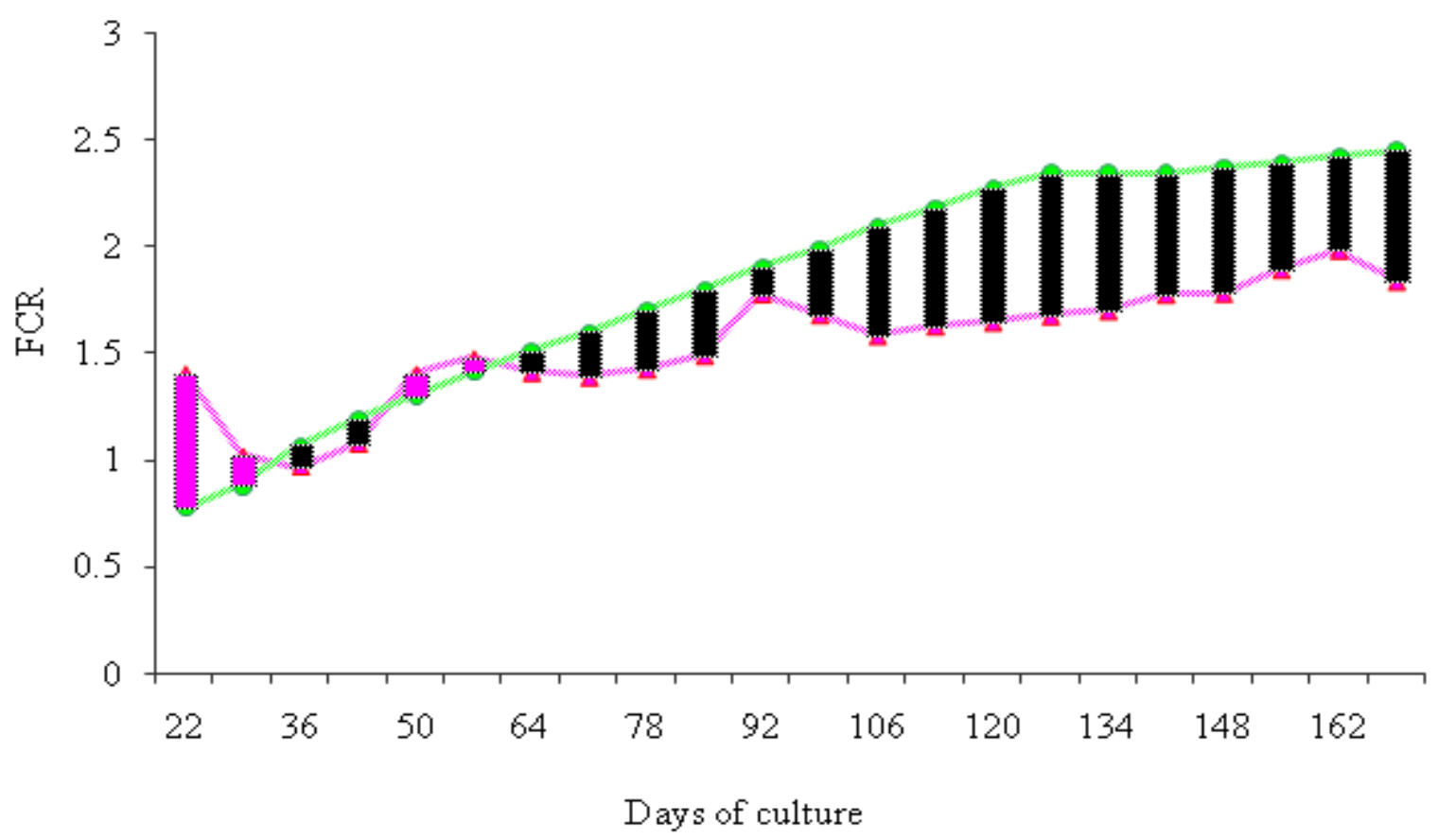

B

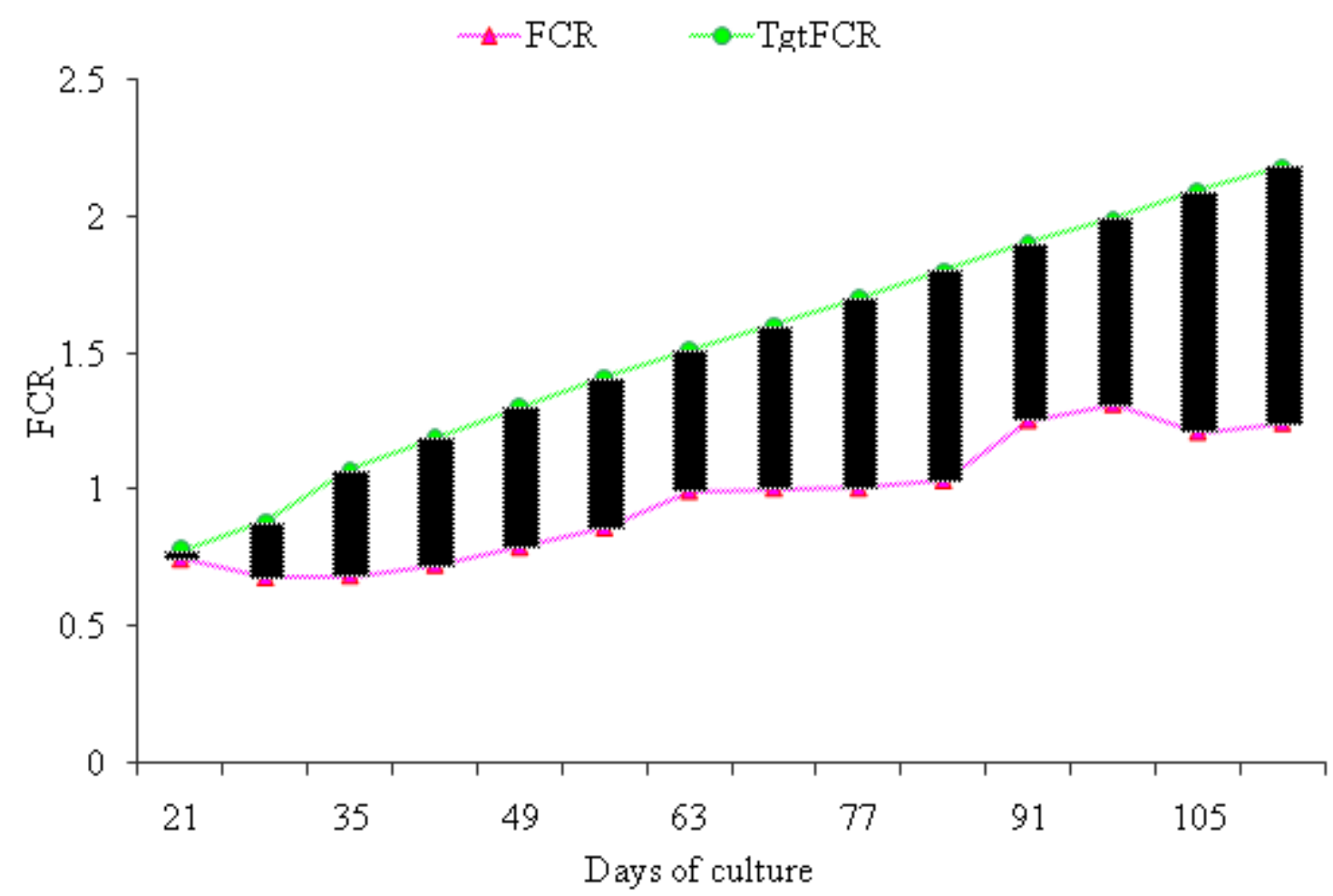

Fig. 7: Food conversion ratio (FCR) of $F$. indicus shrimp in (A) ISHNO and (B) MMWO shrimp ponds. 
A

$\because \mathrm{SR} \quad \mathrm{TgTSR}$

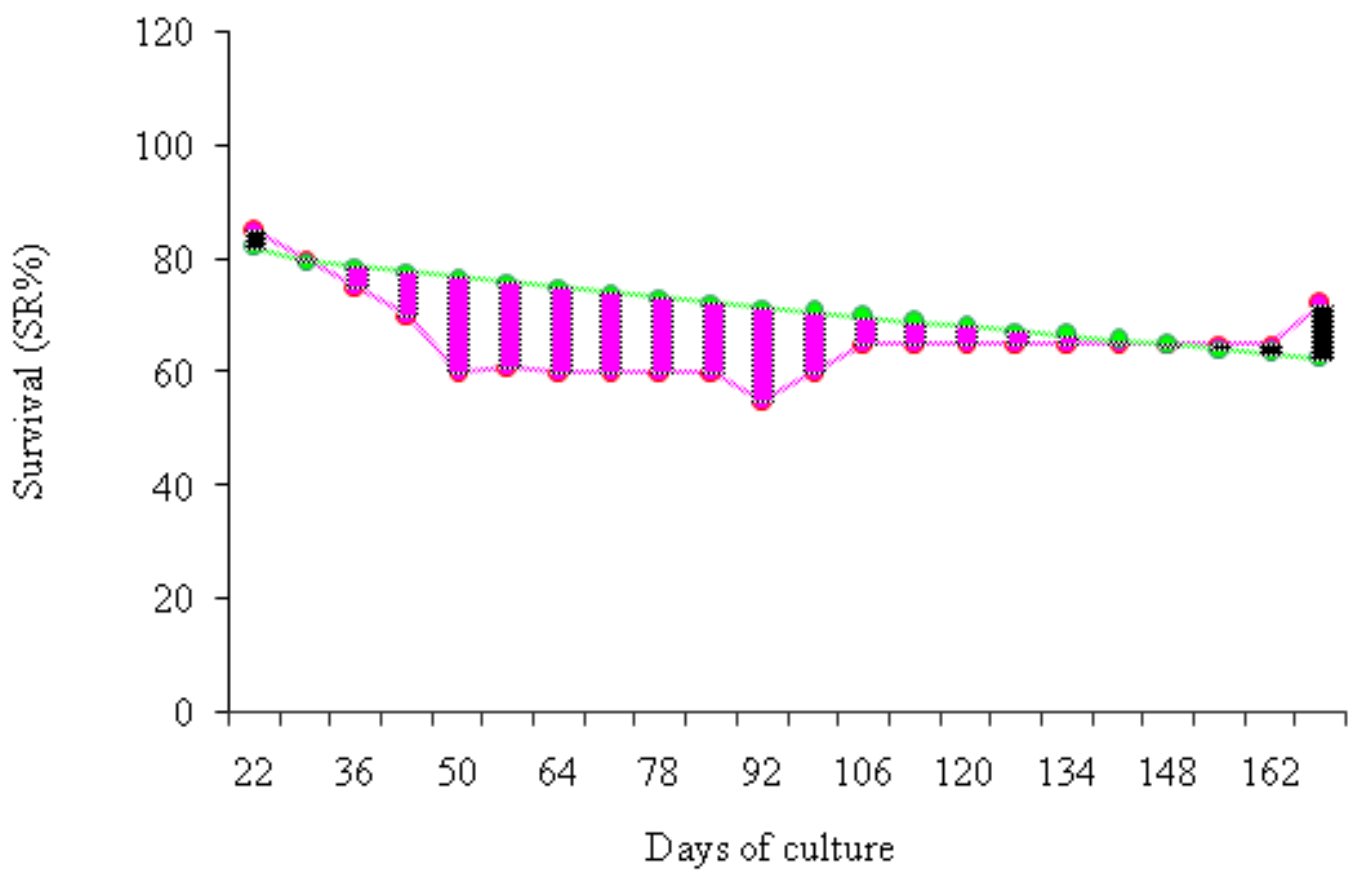

B

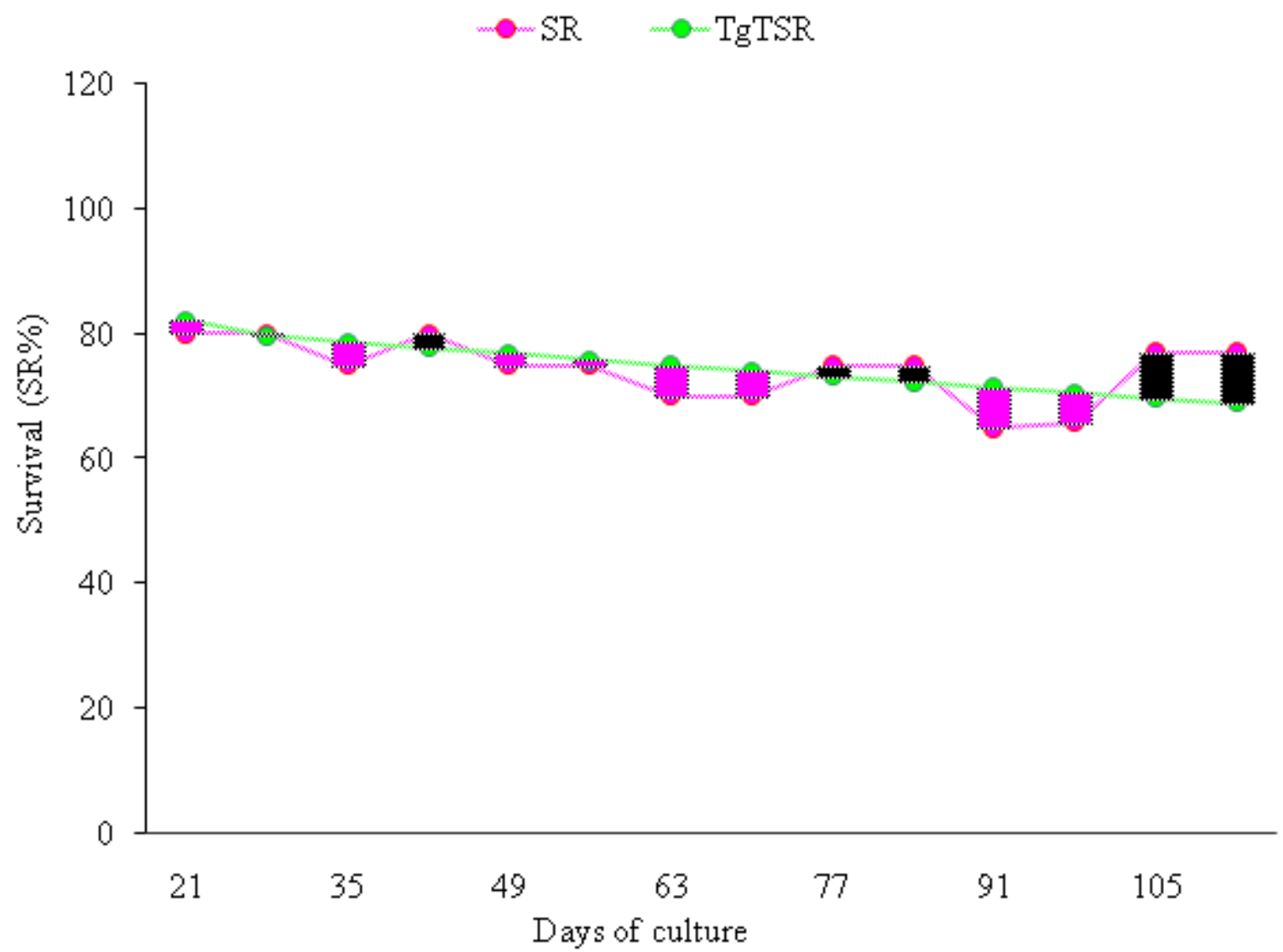

Fig. 8: Survival (SR\%) of F. indicus shrimp in (A) ISHNO and (B) MMWO shrimp ponds. 
However, FCR increases with the age of the shrimp from weak 3 (day 21) to week 16 (day 112) $(0.74 \pm 0.02$ to $1.24 \pm 0.14$, respectively), and the target FCR $(0.78$ to 2.18 , respectively) which was higher than actual FCR values obtained in the current production cycle affected by WSSV. The final biomass of MMWO shrimp ponds was $3132.2 \pm 37.00 \mathrm{~kg} \mathrm{ha}^{-1}$, which was significantly $(P<0.05)$ higher than the target biomass (2113.19 kg ha ${ }^{-1}$ ) (Figs.5a and 5b). Morphometrics represented in weight at collection (CollWt) to the nearest $0.01 \mathrm{~g}$, tail volume (TailV), head length (HeadL), tail length (TailL), maximum head thickness (MaxHThick), tail thickness (TailTK), and maximum thickness of six somite (Max6Somite) were collected on male and female shrimp samples infected with WSSV from ISHNO and MMWO shrimp ponds. The results showed that the random shrimp samples used in the measurements were in good morphometric shape characteristic to $F$. indicus without any deformity and the WSSV does not affect the growth and body shape of the shrimp (Table 1).

\section{Clinical signs, histopathology and PCR of WSSV}

Samples of $F$. indicus obtained from ISHNO shrimp ponds showed opaque abdominal muscles and white, spot on the carapace body cuticle, typical clinical signs of WSD (Figs.3a and 3b). Shrimp were found to be with normal feed intake and survived till harvest. However, moribund shrimp from MMWO shrimp ponds showed white spots on the carapace, reddish discoloration on the body surface and appendages (Figs.3c and 3d). Histopathology of WSD caused by WSSV in F. indicus collected from ISHNO and MMMO shrimp ponds undergoing mass mortalities in Egypt during 2015. In ISHNO shrimp ponds, Overall, the histopathological changes in the tissues of ISHNO (Figs.9a-9f) and MMWO (Figs.10a-10f) shrimps were similar but the severity of changes were more in MMWO compared to ISHNO. These changes were characterized by nuclear hypertrophy, chromatin margination, variable multifocal necrosis and haemocyte encapsulations. Muscle tissues in samples from both locations showed moderate inflammatory cell infiltration between the muscle fibers leading to intermuscular edema, vacuolization and necrosis of muscle fibers. Nucleus hypertrophy and large basophilic intranuclear inclusion bodies were observed in the cuticular epithelium. In addition, nuclear pyknosis and karyorrhexis in the connective tissue, nuclear hypertrophy and dens nucleus were seen in the striated muscles.Gill samples showed congestion and atrophy of secondary lamellae with massive haemocytic infiltration, branchial arches thickened at several sites due to hyperplasia, edema, intranuclear inclusion bodies and haemocytic infiltration.

The histopathological examination revealed that the hepatopancreas showed severe diffuse degeneration represented by vacuolar degeneration and necrosis of hepatocyte with pyknosis of nuclei, sloughing of pancreatic acini epithelium with dilation of the hepatopancreatic tubules and sever inflammation in and around them. In MMWO shrimp ponds, infected nuclei containing Cowdry-like inclusions in the sub-cuticular epidermis and connective tissues. Infected sub-cuticular epidermis and connective tissues associated with the stomach. Classic Cowdry-like inclusions in infected sub-cuticular epidermis and connective tissues. Necrosis of heavily infected sub-cuticular epidermal cells within a limb. Infected haemopoietic tissues with formation and liberation of WSSV-infected haemocytes to haemolymph. Heavily infected and necrotic lymphoid organ with WSSV-infected phagocytic cells (white arrows) and formation of melanised granulomatous lesions. Extracted genomic DNA of 38 (16 Haemolymph and 22 gill tissues) F. indicus shrimp was subjected to amplification by IQ2000 WSSV DPS kit. 
Table 1: Morphometric parameters taken on female and male shrimp collected from WSSV-affected shrimp ponds (ISHNO and MMWO) at day112.

\begin{tabular}{|c|c|c|c|c|c|c|c|c|c|}
\hline ISHNO & MMWO & ISHNO & MMWO & ISHNO & MMWO & ISHNO & MMWO & ISHNO & MMWO \\
\hline $\begin{array}{c}1= \\
\text { male } \\
2= \\
\text { female }\end{array}$ & $\begin{array}{c}1=\text { male } \\
2= \\
\text { female }\end{array}$ & $\begin{array}{l}\text { Weight at } \\
\text { collection }\end{array}$ & $\begin{array}{l}\text { Weight at } \\
\text { collection }\end{array}$ & $\begin{array}{l}\text { Tail volume } \\
\text { (cm3) }\end{array}$ & $\begin{array}{l}\text { Tail volume } \\
\text { (cm3) }\end{array}$ & $\begin{array}{l}\text { Head length } \\
\quad(\mathrm{mm})\end{array}$ & $\begin{array}{l}\text { Head length } \\
\text { (mm) }\end{array}$ & $\begin{array}{l}\text { Tail length } \\
\text { (mm) }\end{array}$ & $\begin{array}{l}\text { Tail length } \\
(\mathrm{mm})\end{array}$ \\
\hline Sex & Sex & CollWt & CollWt & TailV & TailV & HeadL & HeadL & TailL & TailL \\
\hline 2 & 2 & $40.92 \pm 0.31^{b}$ & $43.34 \pm 0.21^{\mathrm{a}}$ & $23.00 \pm 0.19^{\mathrm{a}}$ & $22.00 \pm 0.16^{b}$ & $41.28 \pm 0.10^{\mathrm{a}}$ & $42.32 \pm 0.33^{\mathrm{a}}$ & $60.41 \pm 0.17^{b}$ & $77.23 \pm 0.58^{a}$ \\
\hline 2 & 2 & $36.28 \pm 0.11^{b}$ & $41.39 \pm 0.04^{\mathrm{a}}$ & $20.00 \pm 0.14^{b}$ & $23.00 \pm 0.19^{\mathrm{a}}$ & $42.24 \pm 0.74^{\mathrm{a}}$ & $40.95 \pm 0.92^{b}$ & $61.72 \pm 0.13^{\mathrm{b}}$ & $78.22 \pm 0.32^{\mathrm{a}}$ \\
\hline 2 & 2 & $43.26 \pm 0.15^{\mathrm{a}}$ & $43.05 \pm 0.00^{\mathrm{a}}$ & $21.00 \pm 0.07^{b}$ & $23.00 \pm 0.36^{\mathrm{a}}$ & $43.97 \pm 0.17^{\mathrm{a}}$ & $40.27 \pm 0.35^{b}$ & $78.05 \pm 0.00^{\mathrm{a}}$ & $78.95 \pm 0.39^{\mathrm{a}}$ \\
\hline 2 & 2 & $40.88 \pm 0.22^{\mathrm{a}}$ & $41.94 \pm 0.37^{\mathrm{a}}$ & $22.00 \pm 0.30^{b}$ & $23.00 \pm 0.77^{\mathrm{a}}$ & $39.05 \pm 0.23^{\mathrm{a}}$ & $40.76 \pm 0.11^{\mathrm{a}}$ & $78.66 \pm 0.12^{\mathrm{a}}$ & $78.54 \pm 0.18^{a}$ \\
\hline 2 & 2 & $36.65 \pm 0.20^{b}$ & $42.43 \pm 0.52^{\mathrm{a}}$ & $22.00 \pm 0.34^{\mathrm{a}}$ & $18.00 \pm 0.21^{b}$ & $39.09 \pm 0.19^{b}$ & $44.1 \pm 0.72^{\mathrm{a}}$ & $75.36 \pm 0.30^{\mathrm{a}}$ & $74.55 \pm 0.75^{\mathrm{a}}$ \\
\hline 2 & 2 & $38.18 \pm 0.19^{b}$ & $45.75 \pm 0.33^{\mathrm{a}}$ & $22.00 \pm 0.26^{\mathrm{a}}$ & $20.00 \pm 0.33^{b}$ & $39.53 \pm 0.19^{b}$ & $41.46 \pm 0.13^{\mathrm{a}}$ & $77.92 \pm 0.20^{\mathrm{a}}$ & $76.61 \pm 0.18^{a}$ \\
\hline 2 & 2 & $36.54 \pm 0.53^{b}$ & $40.24 \pm 0.82^{\mathrm{a}}$ & $20.00 \pm 0.13^{b}$ & $22.00 \pm 0.90^{\mathrm{a}}$ & $38.38 \pm 0.33^{b}$ & $43.87 \pm 0.40^{\mathrm{a}}$ & $76.79 \pm 0.14^{\mathrm{a}}$ & $76.87 \pm 0.94^{\mathrm{a}}$ \\
\hline 2 & 2 & $37.64 \pm 0.47^{\mathrm{a}}$ & $33.43 \pm 0.92^{b}$ & $20.00 \pm 0.65^{\mathrm{a}}$ & $16.00 \pm 0.40^{b}$ & $42.25 \pm 0.15^{\mathrm{a}}$ & $40.39 \pm 0.19^{b}$ & $77.22 \pm 0.53^{\mathrm{a}}$ & $73.78 \pm 0.81^{b}$ \\
\hline 2 & 2 & $37.88 \pm 0.73^{b}$ & $44.15 \pm 0.85^{\mathrm{a}}$ & $22.00 \pm 0.27^{b}$ & $23.00 \pm 0.19^{a}$ & $40.35 \pm 0.37^{b}$ & $42.32 \pm 0.11^{\mathrm{a}}$ & $78.27 \pm 0.78^{b}$ & $81.62 \pm 0.14^{\mathrm{a}}$ \\
\hline 2 & 2 & $40.29 \pm 0.29^{\mathrm{a}}$ & $36.82 \pm 0.92^{b}$ & $21.00 \pm 0.25^{\mathrm{a}}$ & $20.00 \pm 0.11^{b}$ & $40.49 \pm 0.22^{\mathrm{a}}$ & $39.84 \pm 0.47^{\mathrm{a}}$ & $80.5 \pm 0.15^{\mathrm{a}}$ & $75.26 \pm 0.32^{b}$ \\
\hline 2 & 2 & $35.13 \pm 0.37^{b}$ & $41.08 \pm 0.00^{\mathrm{a}}$ & $20.00 \pm 0.69^{b}$ & $22.00 \pm 0.13^{\mathrm{a}}$ & $40.92 \pm 0.97^{b}$ & $42.15 \pm 0.11^{\mathrm{a}}$ & $78.66 \pm 0.44^{\mathrm{a}}$ & $78.84 \pm 0.14^{\mathrm{a}}$ \\
\hline 2 & 2 & $37.12 \pm 0.36^{b}$ & $42.46 \pm 0.21^{\mathrm{a}}$ & $20.00 \pm 0.33^{\mathrm{a}}$ & $20.00 \pm 0.19^{a}$ & $42.37 \pm 0.83^{\mathrm{a}}$ & $43.00 \pm 0.35^{\mathrm{a}}$ & $75.00 \pm 0.36^{b}$ & $77.24 \pm 0.62^{\mathrm{a}}$ \\
\hline 2 & 2 & $41.24 \pm 0.61^{\mathrm{a}}$ & $40.58 \pm 0.44^{\mathrm{a}}$ & $24.00 \pm 0.73^{\mathrm{a}}$ & $21.00 \pm 0.27^{b}$ & $42.78 \pm 0.35^{\mathrm{a}}$ & $41.79 \pm 0.15^{\mathrm{a}}$ & $77.55 \pm 0.15^{\mathrm{a}}$ & $78.40 \pm 0.30^{\mathrm{a}}$ \\
\hline 2 & 2 & $35.62 \pm 0.17^{\mathrm{a}}$ & $37.68 \pm 0.13^{\mathrm{a}}$ & $21.00 \pm 0.51^{\mathrm{a}}$ & $20.00 \pm 0.41^{\mathbf{b}}$ & $41.7 \pm 0.13^{\mathrm{a}}$ & $39.78 \pm 0.31^{\mathbf{b}}$ & $76.82 \pm 0.33^{\mathrm{a}}$ & $77.05 \pm 0.36^{\mathrm{a}}$ \\
\hline 1 & 1 & $32.62 \pm 0.16^{\mathrm{a}}$ & $12.50 \pm 0.37^{b}$ & $22.00 \pm 0.48^{\mathrm{a}}$ & $6.00 \pm 0.20^{\mathrm{b}}$ & $39.15 \pm 0.90^{\mathrm{a}}$ & $25.56 \pm 0.11^{b}$ & $76.28 \pm 0.10^{\mathrm{a}}$ & $56.40 \pm 0.78^{b}$ \\
\hline 1 & 1 & $32.70 \pm 0.11^{\mathrm{a}}$ & $12.30 \pm 0.25^{b}$ & $17.00 \pm 0.83^{\mathrm{a}}$ & $6.00 \pm 0.16^{\mathbf{b}}$ & $37.19 \pm 0.40^{\mathrm{a}}$ & $35.31 \pm 0.60^{\mathbf{b}}$ & $77.92 \pm 0.20^{\mathrm{a}}$ & $60.29 \pm 0.40^{\mathbf{b}}$ \\
\hline 1 & 1 & $24.33 \pm 0.16^{\mathrm{a}}$ & $14.00 \pm 0.39^{b}$ & $13.00 \pm 0.14^{\mathrm{a}}$ & $7.00 \pm 0.40^{\mathbf{b}}$ & $32.52 \pm 0.15^{\mathrm{a}}$ & $27.08 \pm 0.68^{b}$ & $72.34 \pm 0.34^{\mathrm{a}}$ & $59.47 \pm 0.11^{b}$ \\
\hline 1 & 1 & $26.40 \pm 0.20^{\mathrm{a}}$ & $11.20 \pm 0.11^{\mathrm{b}}$ & $15.00 \pm 0.57^{\mathrm{a}}$ & $9.00 \pm 0.00^{\mathbf{b}}$ & $33.58 \pm 0.91^{\mathrm{a}}$ & $24.17 \pm 0.54^{b}$ & $76.25 \pm 0.31^{\mathrm{a}}$ & $57.69 \pm 0.80^{b}$ \\
\hline 1 & 1 & $32.27 \pm 0.17^{\mathrm{a}}$ & $11.40 \pm 0.53^{\mathrm{b}}$ & $17.00 \pm 0.23^{\mathrm{a}}$ & $6.00 \pm 0.90^{\mathrm{b}}$ & $36.58 \pm 0.74^{\mathrm{a}}$ & $24.19 \pm 0.19^{b}$ & $80.16 \pm 0.58^{\mathrm{a}}$ & $57.54 \pm 0.58^{\mathrm{b}}$ \\
\hline 1 & 1 & $29.16 \pm 0.59^{\mathrm{a}}$ & $12.20 \pm 0.13^{\mathrm{b}}$ & $15.5 .00 \pm 0.10^{\mathrm{a}}$ & $6.00 \pm 0.31^{b}$ & $34.16 \pm 0.19^{\mathrm{a}}$ & $24.99 \pm 0.68^{b}$ & $75.98 \pm 0.54^{\mathrm{a}}$ & $58.29 \pm 0.13^{b}$ \\
\hline 1 & 1 & $26.27 \pm 0.00^{\mathrm{a}}$ & $15.50 \pm 0.17^{b}$ & $14.00 \pm 0.93^{\mathrm{a}}$ & $8.00 \pm 0.60^{b}$ & $33.83 \pm 0.16^{\mathrm{a}}$ & $27.79 \pm 0.36^{b}$ & $76.51 \pm 0.27^{\mathrm{a}}$ & $63.31 \pm 0.14^{b}$ \\
\hline 1 & 1 & $30.21 \pm 0.19^{\mathrm{a}}$ & $11.80 \pm 0.38^{\mathrm{b}}$ & $16.00 \pm 0.79^{\mathrm{a}}$ & $6.00 \pm 0.13^{b}$ & $35.69 \pm 0.35^{\mathrm{a}}$ & $25.32 \pm 0.13^{b}$ & $78.75 \pm 0.27^{\mathrm{a}}$ & $59.56 \pm 0.68^{b}$ \\
\hline 1 & 1 & $25.34 \pm 0.90^{\mathrm{a}}$ & $14.80 \pm 0.12^{b}$ & $13.50 \pm 0.52^{\mathrm{a}}$ & $8.00 \pm 0.35^{b}$ & $32.55 \pm 0.61^{\mathrm{a}}$ & $27.11 \pm 0.73^{b}$ & $74.07 \pm 0.77^{\mathrm{a}}$ & $61.02 \pm 0.27^{b}$ \\
\hline 1 & 1 & $23.49 \pm 0.91^{\mathrm{a}}$ & $19.40 \pm 0.83^{b}$ & $13.00 \pm 0.75^{\mathrm{a}}$ & $11.00 \pm 0.74^{b}$ & $32.46 \pm 0.12^{\mathrm{a}}$ & $30.00 \pm 0.13^{b}$ & $72.72 \pm 0.32^{\mathrm{a}}$ & $69.53 \pm 0.44^{b}$ \\
\hline 1 & 1 & $22.625 \pm 0.85^{\mathrm{a}}$ & $10.40 \pm 0.00^{b}$ & $12.50 \pm 0.15^{\mathrm{a}}$ & $6.00 \pm 0.13^{b}$ & $31.97 \pm 0.47^{\mathrm{a}}$ & $23.87 \pm 0.29^{b}$ & $72.71 \pm 0.11^{\mathrm{a}}$ & $55.15 \pm 0.11^{b}$ \\
\hline 1 & 1 & $14.30 \pm 0.17^{\mathrm{a}}$ & $15.60 \pm 0.88^{b}$ & $8.00 \pm 0.99^{\mathrm{a}}$ & $8.00 \pm 0.27^{\mathrm{a}}$ & $26.52 \pm 0.29^{\mathrm{a}}$ & $27.67 \pm 0.20^{\mathrm{a}}$ & $61.75 \pm 0.62^{b}$ & $63.17 \pm 0.71^{\mathrm{a}}$ \\
\hline 1 & 1 & $11.70 \pm 0.38^{b}$ & $14.60 \pm 0.091^{\mathrm{a}}$ & $6.00 \pm 0.42^{b}$ & $8.00 \pm 0.53^{\mathrm{a}}$ & $24.61 \pm 0.10^{b}$ & $26.6 \pm 0.26^{\mathrm{a}}$ & $57.04 \pm 0.11^{b}$ & $62.71 \pm 0.29^{\mathrm{a}}$ \\
\hline 1 & 1 & $16.50 \pm 0.27^{b}$ & $32.62 \pm 0.51^{\mathrm{a}}$ & $8.00 \pm 0.22^{b}$ & $22.00 \pm 0.22^{\mathrm{a}}$ & $28.02 \pm 0.00^{b}$ & $39.15 \pm 0.39^{\mathrm{a}}$ & $64.26 \pm 0.13^{b}$ & $76.28 \pm 0.30^{\mathrm{a}}$ \\
\hline 1 & 1 & $11.00 \pm 0.39$ & - & $6.00 \pm 0.13$ & - & $23.96 \pm 0.93$ & - & $56.98 \pm 0.25$ & - \\
\hline 1 & 1 & $12.90 \pm 0.15$ & - & $7.00 \pm 0.16$ & - & $25.52 \pm 0.14$ & - & $61.62 \pm 0.19$ & - \\
\hline
\end{tabular}

Values in the same row, and same parameters with different superscripts are significantly different $(P<0.05)$. 

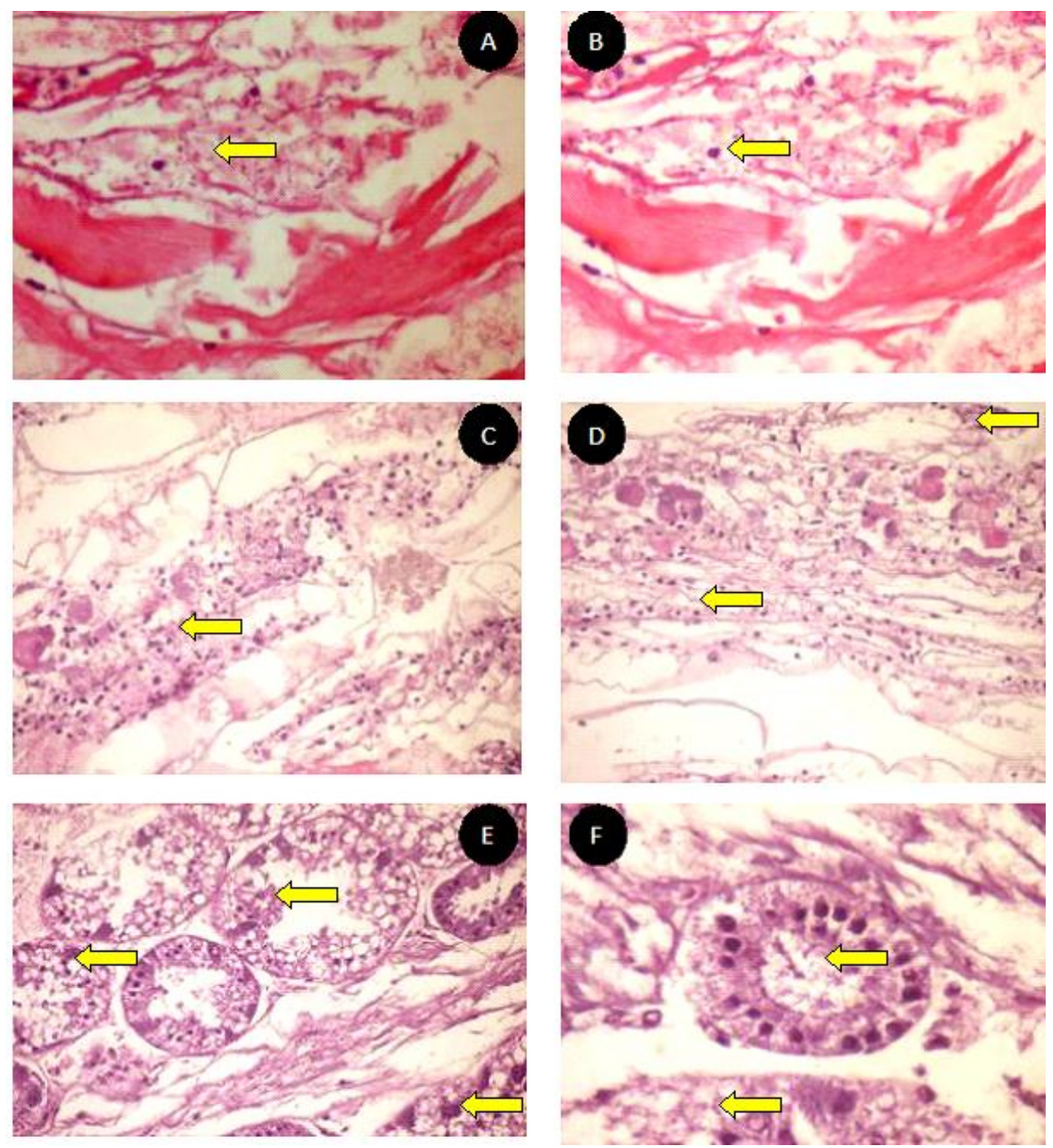

Fig. 9: Light photomicrograph of histological H\&E stained sections through regions of ISHNO shrimp (A-F) WSSV-infected organs of F.indicus. (A-B) Musculature with different types of bacterial colonies in-between muscle fibers (arrow). (C-D) Gills of with hyperplasia, edema and melanomacrophage cell infiltration, cells showing eosinophilic intracellular inclusions surrounded by marginated basophilic chromatin are observed, there is cellular degeneration with nuclear hypertrophy and late stage WSSV-infected nuclei are seen (arrow). (E-F) Hepatopancreas with vacular degeneration and necrosis of hepatocyte (arrow). 

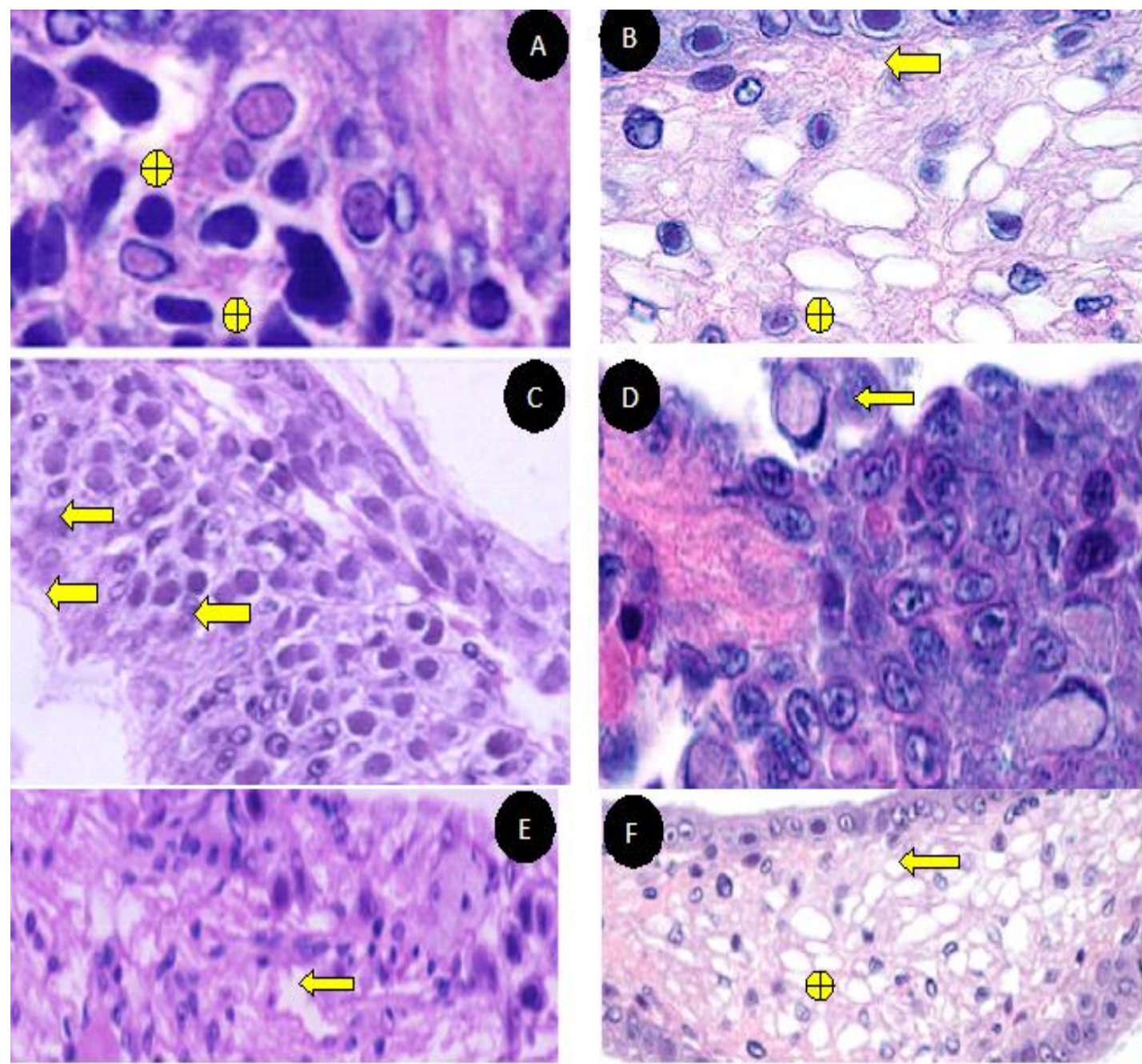

Fig. 10: Light photomicrograph of histological H\&E stained sections through regions of MMWO shrimp (A-F) WSSV-infected organs of F.indicus. (A) Necrosis of heavily infected sub-cuticular epidermal cells (asterisk). (B) Classic Cowdrylike inclusions in infected sub-cuticular epidermis (arrow) and connective tissues (asterisk). (C) Infected nuclei containing Cowdry-like inclusions in the sub-cuticular epidermis (arrows) and connective tissues. (D) Infected haemopoietic tissues with formation and liberation of WSSV-infected haemocytes to haemolymph (arrow). (E) Heavily infected and necrotic lymphoid organ with WSSV-infected phagocytic cells (arrows). (F) Infected sub-cuticular epidermis (arrows) and connective tissues (asterisk) associated with the stomach.

Positive standard DNAs provided by the IQ2000 kits were diluted $\left(10^{3}, 10^{2}\right.$, $10^{1}$ copies) and included in the assays. The IQ2000 kit was designed to generate three amplicons (680 bp, $476 \mathrm{bp}$ and $284 \mathrm{bp}$ ) from a WSSV-infected sample and the presence of only one band indicates absence of WSSV in the sample tested. In PCR amplification, all samples from haemolymph and gill tissues were found to be positive for WSSV (Figs. 11a-11d). 

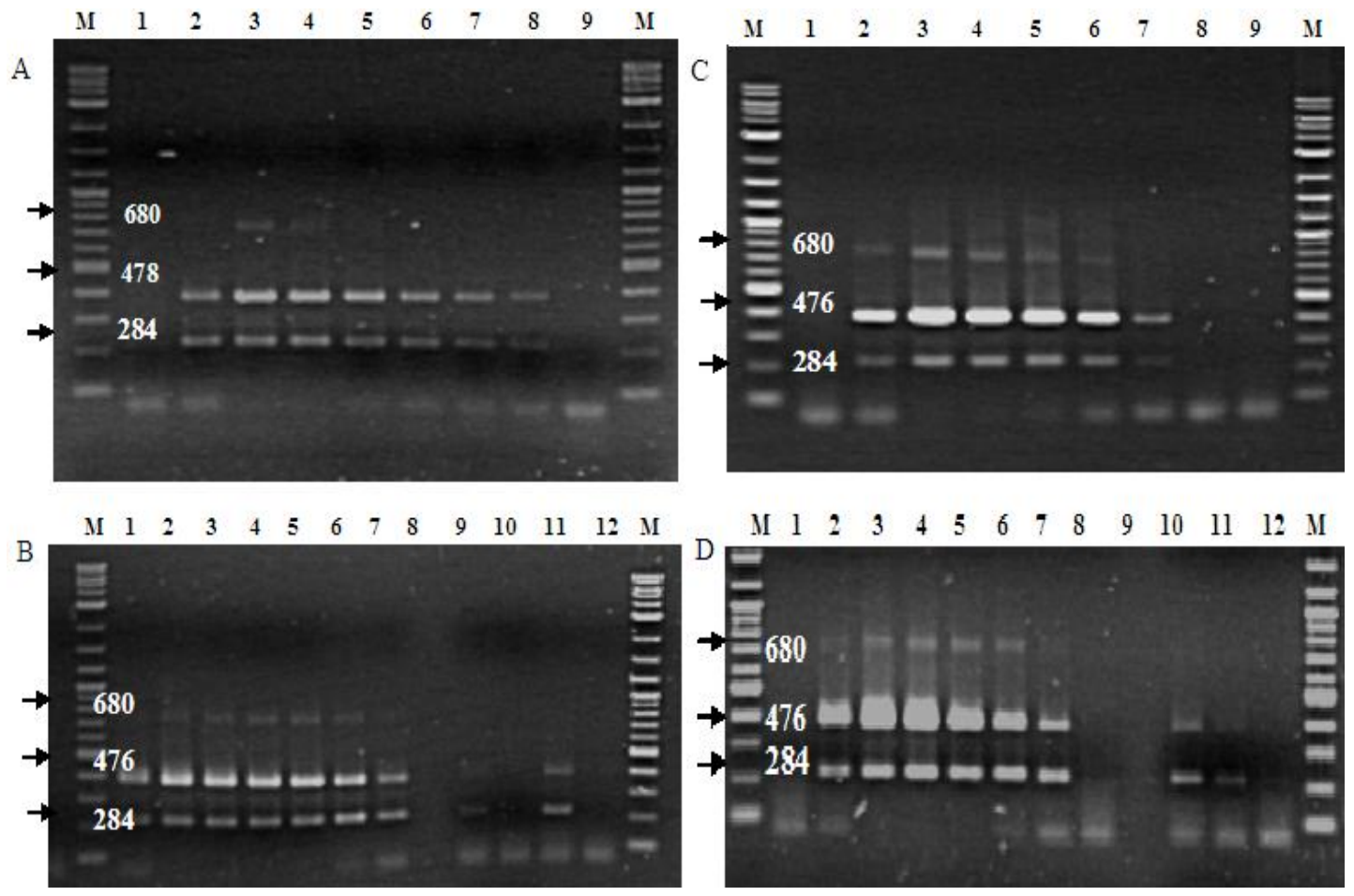

Fig. 11: Agarose gel electrophoresis of PCR amplified WSSV amplicons. (A) $F$. indicus samples from ISHNO shrimp ponds, negative control (lane 1, SPF, $L$. vannamei) and haemolymph samples (lanes 2-9). (B) F. indicus samples from MMWO farm, negative control (lane 1, SPF, L.vannamei) and haemolymph samples (lanes 2-9). (C) F. indicus samples from ISHNO shrimp ponds, negative control (lane 12, SPF, L.vannamei) and gill tissue samples (lanes 111). (D) F. indicus samples from MMWO shrimp ponds, negative control (lane 12, SPF, L.vannamei) and gill tissue samples (lanes 1-11). M= Molecular weight marker. The expected amplicon sizes (680 bp, $476 \mathrm{bp}$ and $284 \mathrm{bp}$ ) are indicted in the photographs.

The MMWO shrimp samples appear to have stronger band intensity compared to the ISHNO shrimp; this may explain why MWWO shrimp experienced mortalities earlier than ISHNO). There were no significant differences $(P>0.05)$ in the number and percentage of infected shrimp between female and male in ISHNO and MMWO shrimp ponds. In ISHNO shrimp ponds, out of 3000 individual taken from a total of 15 random sub - samples, there were 2047 (68.23\%) female and 953 male (31.76\%) infected by WSSV. In MMWO shrimp ponds, out of 3000 individual taken from a total of 15 random samples, there were 2078 (69.26\%) female and 922 (30.73\%) male infected by WSSV (Figs. 12a and 12b). 
A

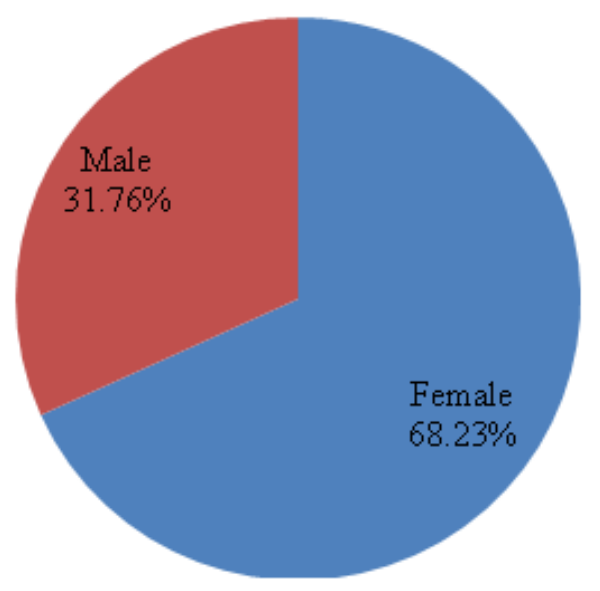

B

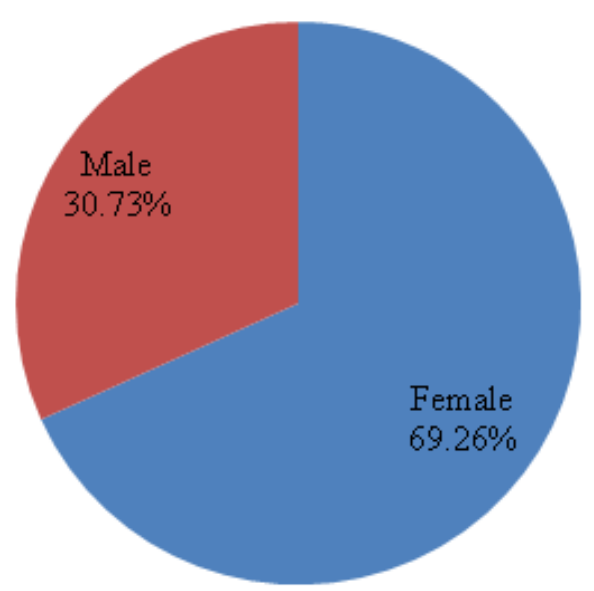

Fig. 12: Percentage of female and male infected with WSSV in (A) ISHNO and (B) MMWO shrimp ponds.

\section{DISCUSSION}

To our knowledge, this is the first paper dealing with the severity of WSSV in shrimp farming in Egypt. The results presented here indicate widespread occurrence of WSSV infection in DTZ shrimp farming site. The first known outbreak of WSSV occurred in farmed shrimp F. indicus in Egypt was in 2010 (Megahed et al., 2013a). From 2015, onwards, shrimp farmers switched to a pathogen free (SPF) L. vannamei, introduced to Egypt from NAQUA, Saudi Arabia. After the first introduction of F.indicus in 2009, the disease became widespread throughout shrimp farms in Egypt, causing economic losses to shrimp farmers. In 2010 the same year F.indicus introduced to Egypt from Saudi Arabia, shrimp farming projects in Saudi Arabia culturing $F$. indicus experienced severe mass mortalities and huge economic losses due to WSSV, which made them shifting to farming L. vannamei. In an attempt to determine the origins of the WSSV responsible for this outbreak, researchers at University of Arizona analyzed the genotypes of the WSSV isolated from $F$. indicus in Saudi Arabia. They identified three different genotypes from different farms (Tang et al., 2012). Two of these differed from the strain of WSSV that originated in Asia and later spread to the Americas. The two Saudi Arabian WSSV genotypes differed from the Asian genotype by having a deletion of 1,522 base pairs from a specific section of the viral DNA (ORF 94); they differed from one another in the number of repeating base pair sequences in ORF 125 (Tang et al., 2012). The evidence suggested that the new genotypes found in Saudi Arabia may have originated in wild $F$. indicus broodstock from the Red Sea (Tang et al., 2012). In Egypt, WSD has been a bottleneck in shrimp farming. While, some farmers managed to obtain a profitable harvest under infection with WSSV, others have suffered serious losses due to the WSD disease caused by WSSV. The objective of this study was to investigate the factors that contribute to the difference in WSD severity with an impact on survivability at harvest in different shrimp farms in Egypt.

The water quality parameters and shrimp growth performance were regularly monitored in an effort to delineate any potential relation of water quality parameters to the observed two categories of disease scenarios, i.e. ISHNO and MMWO shrimp ponds. The results showed that all daily readings of water quality parameters in the ISHNO shrimp ponds were within the accepted range for the production of $F$. indicus 
(Milstein et al., 2005; Zafar et al., 2015). There is evidence in the literature that water quality parameters have an effect on the disease outbreak in shrimp farming (Chang et al., 1998; Maeda et al., 1998). It has also been suggested that exposure of shrimp to stressors increases the risk of WSSV infection, as the stressors can compromise the defense system in shrimp (Takahashi et al., 1995; Chou et al., 1995, Flegel and Alday-Sanz, 1998). For example, Corsin and colleagues studied the risk factors that are associated with WSSV infection in a Vietnamese rice-shrimp farming system. Although these authors found no significant association of disease outbreak with salinity, the WSSV outbreaks were preceded or coincided with higher $\mathrm{pH}$ and un-ionized ammonia (Corsin et al., 2001). It is, therefore, tempting to speculate that some water quality parameters modulate the health status and general immunity in shrimp and affect the spread of disease in the pond. Ammonia is one of the important environmental toxic factors in pond and can affect the immune response, growth and molting, oxygen consumption and ammonia excretion of crustaceans (Gilles, 2000; Zhang et al., 2016). In this study, ammonia-level showed temporal variation in the ponds tested. Ammonia levels fluctuated substantially, between $2.30 \pm 0.71 \mathrm{mg} / \mathrm{L}$ and $2.50 \pm 0.74 \mathrm{mg} / \mathrm{L}$ during the entire growing season. Through the entire study period, a slight increase of $\mathrm{NO}_{2}-\mathrm{N}$ was observed in all the testing ponds. The variation in ammonium-N levels in shrimp ponds might have been caused due to the decrease in DO that negatively impacted the metabolism of nitrobacteria, resulting in an accumulation of ammonia-N.

Temperature is known to affect WSSV infection in L. vannamei (Guan et al., 2003; Gunalan et al., 2010). There was a difference between morning and afternoon temperature in MMWO shrimp ponds and when the water temperature dropped to 24 ${ }^{\circ} \mathrm{C}$, the disease would quickly develop with $100 \%$ mortality. For this reason, MMWO ponds did not continue the whole production cycle and ended at 112 days. Other studies demonstrated that the hyperthermic increases WSSV-induced mortality in L. vannamei shrimp (Guan et al., 2003; Gunalan et al., 2010). Our results showed that mortality due to WSD is significantly reduced when temperature in the range of 28-29 ${ }^{\circ} \mathrm{C}$. Temperature fluctuations greater than $\pm 3^{\circ} \mathrm{C}$ (Esparza et al., 2010; Tendencia et al., 2011) are also conducive to outbreaks of WSSV. This appears to be due to the combined effect of a reduced host immune response and an increase in the rate of viral replication at temperatures less than $28^{\circ} \mathrm{C}$ (Moser et al., 2012). Similar findings were reported by other researchers, this information will help shrimp farmers in Egypt to better manage WSD by avoiding stocking in the cold season. The recommended period for shrimp farming in Egypt is from May to October/November, where temperature is in the optimal range for the shrimp growth and survival.

The average growth rate of the shrimp in this study was $1.07 \pm 0.07 \mathrm{~g}$ week $^{-1}$, which is comparable to the growth rate $(0.9-1.8 \mathrm{~g} / \mathrm{week})$ reported in the literature for the warm season $\left(28\right.$ to $30{ }^{\circ} \mathrm{C}$ ) (Megahed et al., 2013b). The shrimp in the present study reached a commercial size of 20 to $23 \mathrm{~g}$ in five to six months (MayOctober/November). It was intriguing to note that while some shrimp farms were experience large-scale mortalities other were managed to get a profitable harvest despite the presence of the WSD. The ability of shrimp to carry WSSV for relatively long periods under good farming practices and conditions has been previously reported (Tsai et al., 1999; Withyachumnarnkul, 1999; Khadijah et al., 2003). The main effect of WSSV in this study was on the survival rate (Lawrence et al., 2001). In the present study a survival rate of $60-65 \%$ was noticed in semi-intensive commercial ponds (ISHNO or MMWO). Despite 60\% survivability, the recorded 
production level in MMWO WSSV-positive shrimp was $3132.20 \pm 37.00 \mathrm{~kg} \mathrm{ha}^{-1}$, which was acceptable by farmers. In the present study no significant differences in final weight were found between WSSV-infected and non-infected individual shrimp. Based on these results, and considering the existing infrastructure (more than 100 ha of shrimp ponds) in the DTZ, it was conclude that the water quality parameters play an important role for the commercial farming of $F$. indicus during production season from May to October/November. The gross signs, observed in WSSV infected shrimp were: 1) the cuticle was easily separated from the epidermis; 2) the hemolymph was thin and failed to coagulate; and 3) the shrimp reduced feed intake and some cases stopped feeding, and mortality cases occurred within a week after the emergence of gross signs.

All shrimp samples tested by histopathology and PCR were positive for WSSV. The percentage of WSSV infections in female was higher than male in both ISHNO and MMWO shrimp ponds. Considering the fact that WSSV can be vertically transmitted from WSSV-positive spawners to their offspring (Lo et al., 1996a; Lo et al.,1996b; Lo et al., 1999; Hossain et al.,2001), screening and selecting WSSV- negative spawners can potentially reduce WSSV outbreak in grow out ponds.

Tissue sections of affected shrimps showed that the WSSV infected the gills, lymphoid organs, hematopoietic tissue, foregut, stomach, cuticular epidermis, nuclear hypertrophy, and dense basophilic intranuclear inclusions. Despite, viral acute infections associated with mortalities in ISHNO shrimp without clear clinical symptoms of WSSV infection (Lightner,1996; Lightner,1999). The shrimps were normally feeding and no deaths were occurred, which may be due to accommodation of host with the virus (Afsharnasab et al., 2009). Other signs were feeding reduction, as Saberi et al. (2008) reported the reddish body coloration on the moribund shrimp. Also there were differences in intensity virulent WSSV in $F$. indicus compared to other species (especially L. vannamei) which it may be due to different sensitivity of the species, their defensive mechanism and environmental factors of the studied area. Afsharnasab et al. (2009) and Granja et al. (2003) showed that apoptotic cells reduce virus replication and control disease in L. vannamei. Apoptosis plays a critical role in development and maintenance of multicellular organisms. It has also been described as an anti-viral mechanism in both insects and vertebrates. However, in WSD the Cowdry A inclusions represent an early stage of viral infection. Once infecting of these nuclei undergo further degeneration and finally develop into prominent eosinophilic and pale basophilic type inclusions. Existence of nuclear pyknosis and karyorrhexis in the hematopoietic tissue and lymphoid organ were accompanied with losses in tissue structure that implied attack viral infection (Rodriguez et al., 2003). However, in investigated samples, these lesions were associated with severe WSSV infection. Pantoja and Lightner (2003) have observed nuclear pyknosis and karyorrhexis in shrimps that were infected by WSSV experimentally. In addition, pyknosis and karyorrhexis were observed in the hematopoietic tissue of $F$. duorarum with exposure to WSSV experimentally (Wang et al., 2005).

\section{CONCLUSION}

This study reported the existence of two scenarios in WSSV endemic farms, ISHNO and MMWO shrimp ponds. The present study clearly showed that shrimp ponds in DTZ are affected by WSSV and the virus is likely endemic in DTZ. Despite 
the occurrence of WSD outbreaks, some farms managed to maintain the shrimp survive till harvest. The results indicated that there were significant differences in water quality parameters between the two categories of ISHNO and MMWO shrimp ponds which might have contributed to the severity of WSSV infection. It was interesting to note that adult female had a higher rate of infection compared to male. PCR-based diagnostic can be applied to screen for carrier broodstock and postlarvae. Biosecurity should be implemented to prevent future outbreaks. It appears that two common production practices used by farmers in the DTZ increased the vulnerability to WSSV infection: the use of unscreened wild broodstock in the hatcheries, and the reliance on high rates of water exchange in the shrimp ponds. The lack of any disease surveillance programs in Egypt prior to the outbreaks was another factor that contributed to the vulnerability of the shrimp farms. At a national level, there was no governmental response to the WSSV outbreak. Prior to the WSSV outbreak, there was no comprehensive aquatic animal health policy, and there were no functional institutions in place to provide coordinated responses to the crisis. The lack of a national reference laboratory for aquatic animal health resulted in inadequate WSSV surveillance and PCR testing of broodstock that is so needed to prevent any future WSD outbreak. Recovery from the WSSV crisis will require several changes at the farm level.

\section{ACKNOWLEDGEMENTS}

This work was supported by Science \& Technology Development Fund (STDF), Egypt under grants no 5661. The study was carried out with samples collected under the Project "selection for disease resistance in shrimp: selective breeding and molecular technology". The author thanks shrimp farmers in DTZ, Egypt, for their support.

\section{REFERENCES}

Afsharnasab, M.; Mortezaei, R.; Yegane, V. and Kazemi, B. (2009). Gross sign, histopathology and polymerase chain reaction observations of white spot syndrome virus in shrimp specific pathogen free Litopeneaus vannamei in Iran. Asian J. Anim. Vet. Adv., 4: 297-305.

APHA (1998). Standard Methods for the Examination of the Water and Wastewater (22nd ed.). Washington, DC: American Public Health Association.

Bell, T.A. and Lightner, D.V. (1988). A Handbook of Normal Shrimp Histology Special Publication No.1.World Aquaculture Society, Baton Rouge, LA, USA, pp.114.

Chang, P.S.; Chen, L.J. and Wang, Y.C. (1998). The effect of ultraviolet irradiation, heat, $\mathrm{pH}$, ozone, salinity and chemical disinfectants on the infectivity of white spot syndrome baculovirus. Aquaculture, 166: 1-17.

Chen, S.N. (1995). Current Status of Shrimp Aquaculture in Taiwan. In: Swimming Through Troubled Water, Browdy, C.L. and J.S. Hopkins (Eds.). World Aquaculture Society, Baton, Rouge, LA., USA., pp: 29-34.

Chou, H.Y.; Huang, C.Y.; Wang, C.H.; Chiang, H.C. and Lo, C.F. (1995). Pathogenicity of a baculovirus infection causing white spot syndrome in cultured penaeid shrimp in Taiwan. Diseases of Aquatic Organisms, 23: 165173. 
Clifford, H.C. (1985). Semi-intensive shrimp farming. In: G.W. Chamberlain, M.G. Haby \& R.J. Miget (Eds.), Texas Shrimp Farming Manual. Texas Agricultural Extension Service, Corpus Christi, Texas IV, pp. 13-40.

Corsin, F.; Turnbull, J.F.; Hao, N.V.; Mohan, C.V.; Phi, T.T.; Phuoc, L.H.; Tinh, N.T.N. and Morgan, K.L. (2001). Risk factors associated with white spot syndrome virus infection in a Vietnamese rice-shrimp farming system. Diseases in Aquatic Organisms, 47: 1-12.

Esparza-Leal, H.M.; Magallón-Barajas, F.J.; Portillo-Clark, G.; Pérez-Enríquez, R.; Alvarez-Ruíz, P.; Escobedo-Bonilla, C.M.; Méndez-Lozano, J.; Mañón-Ríos, N.; Valerio-García, C.; Hernández-López, J.; Vivanco-Pérez, N. and CasillasHernández, R.(2010). Infection of WSSV-negative Shrimp, Litopenaeus vannamei, Cultivated under Fluctuating Temperature Conditions. Journal of the World Aquaculture Society, 41(6): 912-922.

Fegan, D.F.; Flegel, T.W.; Sriurairatana, S. and Waiakrutra, M. (1991). The occurrence, development and histopathology of monodon baculovirus in Penaeus monodon in Southern Thailand. Aquaculture, 96: 205-217.

Flegel, T.W. and Alday-Sanz, V. (1998). The crisis in Asian shrimp aquaculture, current status and future needs. Journal of Applied ichthyology, 14: 269-273.

Flegel, TW. (1997a). Major viral diseases of the black tiger prawn (Penaeus monodon).World Journal of Microbiology and Biotechnology, 13: 433-442.

Flegel, TW. (1997b). Special topic review: major viral diseases of the black tiger prawn (Penaeus monodon) in Thailand. World Journal of Microbiology and Biotechnology, 13: 433-442.

Gilles, L.M. and Philippe, H. (2000). Environmental factors affecting immune responses in Crustacea. Aquaculture, 191 (1-3): 121-131.

Granja, C.B., Aranguren, L.F.; Vidal, O.M.; Aragon, L. and Salazar, M. (2003). Does hyperthermia increase apoptosis in White Spot Syndrome Virus (WSSV)infected Litopenaeus vannamei? Dis. Aquat. Org., 54: 73-78.

Guan, Y.; Yu. Z. and Li, C. (2003). The effect of temperature on white spot syndrome infections in Marsupenaeus japonicus. Journal of Invertebrate Pathology, 83: 257-260.

Gunalan, B.; Soundarapandian, P. and Dinakaran, G.K. (2010). The effect of temperature and $\mathrm{pH}$ on WSSV infection in cultured marine shrimp Penaeus monodon (Fabricius). Middle East Journal of Scientific Research, 5: 28-33.

Hossain, M.S.; Chakraborty, A.; Joseph, B.; Otta, S.K.; Karunasagar, I. and Karunasagar, I. (2001). Detection of new hosts for white spot syndrome virus of shrimp using nested polymerase chain reaction. Aquaculture, 198: 1-11.

Kautsky, N.; Rönnbäck, P.; Tedengren, M. and Troell, M. (2000). Ecosystem perspectives on management of disease in shrimp pond farming. Aquaculture, 191:145-161.

Khadijah, S.; Neo, S.Y.; Hossain, M.S.; Miller, L.D.; Mathavan, S. and Kwang, J. (2003). Identification of white spot syndrome virus latency-related genes in specific-pathogen-free shrimps by use of a microarray. Journal of Virology, 77: $10162-10167$.

Lan, Y.; Lu, W. and Xu, X. (2002). Genomic instability of prawn white spot bacilliform virus (WSBV) and its association to virus virulence. Virus Research, 90: 269-274.

Lawrence, A.L.; More, W.; Bray, W.A. and Royo, M. (2001). Successful intensive culture of Litopenaeus vannamei on a white spot syndrome virus-contaminated farm in Panama. Aquaculture 2001, Lake Buena Vista, FL (USA), 21-25 Jan 
2001. Aquaculture 2001: Book of Abstracts, World Aquaculture Society, 143 J.M Parker Coliseum Louisiana State University, Baton Rouge, L.A, USA, 2001, 753 p.

Lightner, D.V. (1996). Epizootiology, distribution and the impact on international trade of two penaeid shrimp viruses in the Americas. Revue Scientifique et Technique Office International des Epizooties 15: 579-601.

Lightner, D.V. (1999). The penaeid shrimp viruses TSV, IHHNV, WSSV and YHV: Current status in the Americas, available diagnostic methods and management strategies. J. Applied Aquacult., 9: 27-52.

Liu, B.; Yu, Z.M.; Song, X.X.; Guan, Y.Q.; Jian, X.F. and He, J.G. (2006). The effect of acute salinity change on white spot syndrome (WSS) outbreaks in Fenneropenaeus chinensis. Aquaculture, 253:163-170.

Lo, C.F.; Leu, J.H.; Ho, C.H.; Chen, C.H.; Peng, S.E.; Chen, Y.T.; Chou, C.M.; Yeh, P.Y.; Huang, C.J.; Chou, H.Y.; Wang, C.H. and Kou, G.H.(1996a). Detection of baculovirus associated with white spot syndrome (WSSV) in penaeid shrimps using polymerase chain reaction. Diseases of Aquatic Organisms, 25: 133-141.

Lo, C.F.; Ho, C.H.; Peng, S.E.; Chen, C.H.; Hsu, H.C.; Chiu, Y.L.; Chang, C.F.; Liu, K.F.; Su, M.S.; Wang, C.H, and Kou, G.H.(1996b). White spot syndrome baculovirus (WSBV) detected in cultured and captured shrimp, crabs and other arthropods. Diseases of Aquatic Organisms, 27: 212-225.

Lo, C.F.; Hsu, H.C.; Tsai, M.F.; Ho, C.H.; Peng, S.E.; Kou, G.H. and Lightner, D.V. (1999). Specific genomic DNA fragment analysis of different geographical clinical samples of shrimp white spot syndrome virus. Dis Aquat Org 35:175185.

Lotz, J.M.; Anton, L.S. and Soto, M.A. (2005). Effect of chronic Taura syndrome virus infection on salinity tolerance of Litopenaeus vannamei. Diseases of Aquatic Organisms, 65: 75-78.

Maeda, M.; Kasornchandra, J.; Itami, T.; Suzuki, N.; Hennig, O.; Kondo, M.; Albaladejo, J.D. and Takahashi, Y. (1998). Effect of various treatments on white spot syndrome virus (WSSV) from Penaeus japonicus (Japan) and $P$. monodon (Thailand). Fish Pathology, 33: 381-387.

Megahed, M.E.; Ghoneim, S.; Desouky, G. and Dakar AE. (2013a). Major Constraints Facing Development of Marine Shrimp Farming in Egypt. Journal of the Arabian Aquaculture Society, 8:321-330.

Megahed E.M.; Ghoneim, S.; Desouky, G. and Dakar, A.E. (2013b). Pilot Experiment on Shrimp P. semisulcatus Production at Al - Deba Farm Site. Journal of the Arabian Aquaculture Society, 8 (2); 331-338.

Milstein, A.; Islam, M.S.; Wahab, M.A.; Kamal, A.H.M. and Dewan, S. (2005). Characterization of water quality in shrimp ponds of different sizes and with different management regimes using multivariate statistical analysis. Aquaculture International, 13 (6): 501-518.

Moser, J.R.; Álvarez, D.A.G.; Cano, F.M.; Garcia, T.E.; Molina, D.E.C.; Clark, G.P.; Marques, M.R.F.; Barajas, F.J.M. and López, J.H.(2012). Water temperature influences viral load and detection of white spot syndrome virus (WSSV) in Litopenaeus vannamei and wild crustaceans. Aquaculture, 326: 9-14.

Owens, L.; Haqshenas, G.; MeElnea, C. and Coelen, R. (1998). Putative spawner isolated mortality virus associated with mid-crop mortality syndrome in farmed Penaeus monodon from northern Australia. Disease of Aquatic Organisms, 34: 177-185. 
Pantoja, C.R. and Lightner, D.V. (2003). Similarity between the histopathology of white spot syndrome virus and yellow head syndrome virus and its relevance to diagnosis of YHV disease in the Americas. Aquaculture, 218: 47-54.

Peinado-Guevara, L.I. and Lopez-Meyer, M. (2006). Detailed monitoring of white spot syndrome virus (WSSV) in shrimp commercial ponds in Sinaloa, Mexico, by nested PCR. Aquaculture, 251: 33-45.

Rahman, M.M.; Escobedo-Bonilla, C.M.; Corteel, M.; Dantas-Lima, J.J.; Wille, M.; Alday, S.M.V.; Pensaert, M,B.; Sorgeloos, P. and Nauwynck, H.J.(2006). Effect of high water temperature $\left(33^{\circ} \mathrm{C}\right)$ on the clinical and virological outcome of experimental infections with white spot syndrome virus (WSSV) in specific pathogen-free (SPF) Litopenaeus vannamei. Aquaculture, 261:842849.

Rodriguez, J.; Bayot, B.; Amano, Y.; Panchana, F. ; de Blas, I. ; Alday, V. and Caleron, J. (2003). White spot syndrome virus infection in cultured Penaeus vannamei (Boone) in Ecuador with emphasis on histopathology and ultrastructure. J. Fish Dis., 26: 439-450.

Ruiz-Velazco, J.M.J.; Hernández-Llamas, A.; Gomez-Muñoz, V.M. and Magallon F.J. (2010). Dynamics of intensive production of shrimp Litopenaeus vannamei affected by white spot disease. Aquaculture, 300:113-119.

Saberi, A.M.; Bandehpour, M.; Afsharnasab, M.; Ghayour, E. ; Yousefi Namin, S.A. and B. Kazemi, (2008). Designing and introduce a diagnostic kit for detection of white spot syndrome virus in cultured Penaeus indicus in Iran. Pak. J. Biol. Sci., 11: 2660-2664.

Sánchez-Martínez, J.G.; Aguirre-Guzmán, G. and Mejía-Ruíz, H. (2007). White spot syndrome virus in cultured shrimp: a review. Aquaculture Research, 38: 13391354.

Takahashi,Y.; Itami, T. and Kondo, M. (1995). Immunodefense System of Crustacea. Fish Pathology, 30: 141-150.

Tang, K.F.; Navarro, S.A.; Pantoja, C.R.; Aranguren, F.L. and Lightner, D.V. (2012). New genotypes of white spot syndrome virus (WSSV) and Taura syndrome virus (TSV) from the Kingdom of Saudi Arabia. Diseases of Aquatic Organisms, 99:179-185.

Tendencia, E.A. and Verreth, J.A.J. (2008). Temperature fluctuations, low salinity and water microflora are risk factors for WSSV outbreaks in pond culture of Penaeus monodon. In Abstracts of World Aquaculture Society Meeting. May 2008. Busan, Korea: 2011.

Tendencia, E.A.; Bosma, R.H.; Usero, R.C. and Verreth, J.A.J. (2010). Effect of rainfall and atmospheric temperature on the prevalence of the white spot syndrome virus in pond cultured Penaeus monodon. Aquaculture Research, 41:594-597.

Tendencia, E.A.; Bosma, R.H. and Verreth J.A.J. (2011). White spot syndrome virus (WSSV) risk factors associated with shrimp farming practices in polyculture and monoculture farms in the Philippines. Aquaculture, 311: 87-93.

Tsai, M.F.; Kou, G.H.; Liu, H.C.; Liu, K.F. and Chang, C.F. (1999). Long-term presence of white spot syndrome virus (WSSV) in a cultivated shrimp population without disease outbreaks. Diseases of Aquatic Organisms, 38:107114.

Vidal, O.M.; Granja, C.B.; Aranguren, F.; Brock, J.A. and Salazar, M. (2001). A profound effect of hypothermia on survival of Litopenaeus vannamei juveniles 
infected with white spot syndrome. Journal of the World Aquaculture Society, 32:364-372.

Wang, Q.; White, B.L.; Redmanm R.M. and Lightner, D.V. (2005). Peros challenge of litopenaeus vannamei postlarvae and farfantepenaeus duorarum juveniles with six geographic isolates of white spot syndrome virus. Aquaculture, 250: 586-591.

Withyachumnarnkul, B. (1999). Results from black tiger shrimp Penaeus monodon culture ponds stocked with postlarvae PCR-positive or-negative for white-spot syndrome virus (WSSV). Diseases of Aquatic Organisms, 39: 21-27.

Wyban, J. A.; Swingle, J. S.; Sweeney, J. N. and Pruder, G. D. (1992). Development and commercial performance of high health shrimp using specific pathogen free (SPF) broodstock Penaeus vannamei. Proceedings of the Special Session on Shrimp Farming, April 27-30, 1992, Baton Rouge, Louisiana, pp: 254-260.

Yu, Z.; Li, C.; and Guan, Y. (2003). Effect of salinity on the immune responses and outbreak of white spot syndrome in the shrimp Marsupenaeus japonicus. Ophelia, 57: 99-106.

Zafar, M.A.; Haque, M.M.; Aziz, M.S.B. and Alam, M.M. (2015). Study on water and soil quality parameters of shrimp and prawn farming in the southwest region of Bangladesh. Journal of the Bangladesh Agricultural University, 13(1): 153-160.

Zhang, J.S.; Li, Z.J.; Wen, G.L.; Wang, Y.L.; Luo, L.; Zhang, H.J. and Dong, H B. (2016). Relationship between white spot syndrome virus (WSSV) loads and characterizations of water quality in Litopenaeus vannamei culture ponds during the tropical storm. Iranian J. Vet. Res., 17(3): 210-214. 